\title{
LAS TRADICIONES IDEOLÓGICAS DE LA EXTREMA DERECHA ESPAÑOLA
}

\author{
por
}

\author{
Pedro Carlos González Cuevas \\ U.N.E.D.
}

RESUMEN: $\quad$ El concepto de «extrema derecha» abarca, tanto a nivel de pensamiento como de práctica política, un conjunto de «tradiciones» coincidentes en su rechazo del pluralismo político, en la defensa de sistemas de carácter autoritario o totalitario, en una perspectiva antropológica pesimista y en una acción social antirrevolucionaria $y$, a la vez, reformista. Pero separadas entre sí en no pocos aspectos. Podemos distinguir, así, entre diversas "tradiciones» de extrema derecha: la «teológico política» — tradicionalista—, basada en la preeminencia del factor religioso; la «radical», que asume los supuestos seculares de la modernidad e intenta fundamentar su discurso en factores no religiosos: raza, nación, etc., y la "revolucionaria» —o fascista-, cuyo proyecto político tiene por base una sintesis de elementos socialistas, nacionalistas y populistas, elaborada desde una perspectiva antiliberal y antimarxista. Estas "tradiciones» pueden ser clasificadas, según su vigencia social, en «hegemónicas», «residuales» $y$ «emergentes». A juicio del autor, lo característico de la situación española es el mantenimiento de la "tradición» teológico-política como begemónica basta bien entrado el siglo XX; y la situación subordinada de la radical y de la revolucionaria.

Palabras clave: España. Historia Contemporánea. Extrema Derecha.

ABSTRACT: The term "extreme right» encompasses a range of "traditions» which bave in common a rejection of political pluralism, a defence of authoritarian or totalitarian systems, a pessimistic view of man and an anti-revolutionary social policy. But these traditions are distinguished from each other in several aspects. We can separate several traditions on the extreme right: "political theology», based on the religious factor; the "radical» tradition, which emphasises secular factors such as race and nation, and the "revolutionary" or fascist tradition, based on a synthesis of socialistic, nationalistic and populist elements and an anti-liberal and antiMarxist perspective. These traditions can be classified, according to their prevalence in society, as "hegemonic», "residual» or "emerging». In the author's view, the characteristic feature of the Spanish situation is the maintenance of "political 
theology" as a begemonic tradition well into the twentieth century, and the subordinate importance of the radical and revolutionary positions.

KEY WORDS: Spain. Modern History. Extreme Right.

\section{INTRODUCCIÓN}

El concepto de «extrema derecha» designa, tanto a nivel de praxis como de pensamiento político, una pluralidad de «tradiciones» unidas por temas, objetivos y, sobre todo, por enemigos comunes; pero igualmente hostiles entre sí en no pocos aspectos. Entendemos por «tradición» un «razonamiento extendido a lo largo del tiempo en el que ciertos acuerdos se definen y redefinen en términos de dos tipos de conflictos: los que tienen lugar con críticos y enemigos externos a la tradición, que rechazan todos o casi todos los elementos claves de los acuerdos fundamentales y aquellos otros debates internos e interpelativos por medio de los cuales se llegan a expresar el sentido y el motivo de esos acuerdos fundamentales y en el progreso de los cuales se constituye la tradición». Cada una de estas tradiciones posee sus propias pautas internas para calibrar y dar respuesta a la problemática de su época. Pero, en un momento dado, pueden entrar en un período de crisis que las lleve a desaparecer, al serle imposible renovarse y reducir el número de problemas que tienen planteados. Cuando una "tradición» se inclina en este sentido - cuando está afectada por conflictos estériles y se limita a repetir las viejas fórmulas- se halla en una "crisis epistemológica», y solo podrá superarla elaborando una serie de conceptos o una nueva síntesis de doctrinas e ideas, un marco de referencia que reúna estos tres requisitos: que permita a la "tradición» resolver sus problemas pendientes, que explique como se plantearon y por qué no se habían resuelto hasta ahora, y que haga ambas cosas destacando la continuidad básica existente entre la síntesis anterior y la nueva. Nunca está garantizado que pueda llevarse a cabo esa innovación conceptual dentro de la «tradición». Por ello, una «tradición» no sólo puede entrar en un período de decadericia, sino incluso desaparecer como consecuencia de esa crisis ${ }^{1}$

Cada crisis corresponde al impacto de los acontecimientos políticos, sociales, económicos, culturales e ideológicos que, por su repercusión, obligan a las distintas «tradiciones» a una redefinición. Y en ese sentido, resulta útil distinguir, por emplear la terminología de Raymond Williams, entre tradiciones «dominantes», «emergentes»y «residuales»².

Por «dominantes» entendemos aquellas tradiciones que, durante largo tiempo, son capaces de configurar el pensamiento y el proyecto político de los sectores ubicados en la «extrema derecha»; y de adaptar sus contenidos a las

1 MacinTYRe, Alasdair: Justicia y racionalidad. Barcelona, 1994, páginas 394 y ss.

2 Williams, Raymond: Marxismo y literatura, Barcelona, 1980, páginas 143 y ss.

Hispania, LXI/1, núm. 207 (2001) 99-142 
nuevas formas económicas, sectores sociales e incluso a los nuevos valores, sin perder por ello sus características esenciales. «Emergente» sirve aquí para designar la génesis y configuración de nuevos estilos de pensamiento que llevan consigo proyectos, significaciones, valores y prácticas políticas de «extrema derecha», que entran en conflicto con la tradición hasta entonces dominante, consiguiendo convertirla en «residual», es decir, en anacrónica y disfuncional, incapaz de superar los nuevos retos sociales, sumiéndose en una irreversible crisis epistemológica. En ese sentido, podemos distinguir, tanto a nivel europeo como específicamente español, tres «tradiciones» de extrema derecha. La «teológico política» - $\mathrm{O}$ tradicionalista, a secas-, cuyo proyecto ideológico intenta la sistematización del hecho religioso como legitimador de la práctica política. $\mathrm{La}$ «radical», que, frente a la anterior, asume los supuestos seculares de la modernidad e intenta legitimar su discurso en valores no religiosos como la nación o la raza, y en nociones científicas extraídas de la biología, la etnología, la sociología o la jurisprudencia. Y, por último, la «revolucionaria» —o fascista-, cuyo proyecto político, producto de una época caracterizada por la movilización de las masas, se presenta como una síntesis de elementos nacionalistas, populistas y socialistas, elaborada en un sentido abiertamente antiliberal y antimarxista. Por supuesto, la vigencia y el carácter de estas «tradiciones» se encuentra determinado por las características culturales de sus sociedades nacionales. No existe «extrema derecha» en sí; sólo existen sociedades nacionales, cada una de las cuales potencia determinadas tradiciones y otras no. En el caso español, la "tradición» dominante ha sido la «teológico-política», a lo largo de todo el siglo XIX y buena parte del XX. La perspectiva católica dotó a la extrema derecha española de unos esquemas de interpretación cargados de símbolos, mitos, imágenes, de todo un repertorio de significados sobre causalidades y acontecimientos del mundo: el providencialismo, la lucha del Bien contra el Mal como motor de la Historia, la «causalidad diabólica» o la Edad de Oro perdida, etc. Además, la Iglesia católica consiguió presentarse como portadora de una «ideología nacional», es decir, de una orientación hegemónica, que durante mucho tiempo apenas fue conmovida por tendencias contrarias e hizo pasar por herético, por no-nacional cualquier otro pensamiento que le fuera inasimilable. Ello fue causa y, al mismo tiempo, efecto de la debilidad del nacionalismo español. El Estado liberal español fue, dado el atraso social y económico del país, un Estado muy débil, incapaz de lograr una efectiva «nacionalización de las masas» y de crear un ritual, una serie de símbolos capaces de estimular un sentimiento nacional fuerte al margen de la identidad religiosa. A ello se unió el papel secundario de la nación española en la sociedad internacional contemporánea; y la consiguiente ausencia de un enemigo exterior.

Por todo ello, la tradición "radical», nacionalista y laica, fue no sólo más tardía que en la mayoría de los países europeos, sino mucho más débil. En realidad, sus primeras manifestaciones de envergadura fueron los nacionalismos periféricos catalán y vasco, nacidos al socaire de la crisis finisecular. En el resto 
de España, sólo comenzó sus primeros balbuceos a lo largo de la crisis del sistema de la Restauración, para luego adquirir una mayor, aunque muy pequeña, difusión, en sus perfiles menos extremos durante la II República. Y lo mismo ocurrió, en consecuencia, con la "revolucionaria», cuya principal característica fue su marginalidad social y política hasta el estallido de la guerra civil. Fueron, pues, dos tradiciones «emergentes» incapaces de desplazar a la «dominante», que sólo a partir de los años sesenta entró en una irreversible crisis epistemológica, al socaire de las transformaciones sociales y las consecuencias del Concilio Vaticano II.

En ese sentido, el pensamiento político de la extrema derecha española se caracteriza por una continuidad que no se da en el resto de los países europeos. Ajena a planteamientos de carácter racista o imperialista, su originalidad histórica radica en su inquebrantable y permanente voluntad restauradora de los valores católicos y en su oposición a los principios configuradores del proyecto de la modernidad.

\section{LA REACCIÓN «A LO DIVINO»}

Como ha señalado François Furet, el momento clave de lo que podemos llamar «revolución liberal-democrática» ha de ubicarse en la Revolución francesa, ya que fue a nivel del imaginario social que surgió algo verdaderamente nuevo con la afirmación del poder popular. Es allí, según él, donde se sitúa la verdadera discontinuidad: en el establecimiento de una nueva legitimidad, en la invención de una cultura democrática ${ }^{3}$. Esta mutación significa el cuestionamiento de un tipo de sociedad jerárquica y desigualitaria, regida por una lógica teológico-política, en la que el orden social se encontraba fundamentado en la voluntad divina y en la que el cuerpo social era concebido como un todo en el que los individuos aparecían fijados en posiciones diferenciadas.

Sin este reto político-ideológico resulta imposible comprender la emergencia del conservadurismo o del tradicionalismo como estilos de pensamiento, nacidos de la experiencia de discontinuidad entre el presenta y el pasado. Básicamente, se trata, como señaló Mannheim, de «la expresión de una tradición feudal que se ha vuelto consciente ${ }^{4}$.

En el caso español, la discontinuidad en el imaginario social tiene su más directo origen en la agresión napoleónica de 1808, que produjo la reacción nacional conocida como Guerra de la Independencia; y cuya primera consecuencia fue el hundimiento, a nivel político e institucional, del Antiguo Régimen, que de inmediato sustituido, a veces mediante las mismas personas, por

\footnotetext{
3 FURET, François: Pensar la Revolución francesa, Barcelona, 1980, páginas, 109 y ss.

${ }^{4}$ MANnheim, Karl: Ideología y utopía, México, 1987, páginas, 107 y ss. «El pensamiento conservador», en Ensayos sobre sociología y psicología social, México, 1963, páginas 70 y 84.
}

Hispania, LXI/1, núm. 207 (2001) 99-142 
nuevas instituciones de soberanía popular - las Juntas-, que posteriormente darían lugar a las Cortes de Cádiz, las primeras Cortes constituyentes de la historia de España. En las Cortes constituyentes, se configuraron los grupos políticos que, en cierta forma, estaban ya prefigurados desde la época de la Ilustración: «realistas» y liberales. El sector realista no fue un sector homogéneo; en él convivieron los defensores radicales del Antiguo Régimen y los sectores conservadores reformistas de inspiración jovellanista. El primero de estos sectores se caracterizó por la defensa de los privilegios estamentales de la nobleza, del clero y de la Monarquía; y por la crítica del despotismo ilustrado, con vistas a la restauración de la España de los Austrias. Mientras que el segundo se mostraba partidario de llevar a cabo ciertas reformas liberalizadoras en la economía y en la sociedad, así como de reforzar las prerrogativas del reys. A efectos de nuestro trabajo, nos interesa, ante todo, el primer grupo; el segundo es un claro precedente del liberalismo conservador posterior, cuyas tesis políticas llegarían a ser hegemónicas a lo largo de todo el siglo XIX ${ }^{6}$.

Entre los diputados «realistas» destaca Pedro de Inguanzo y Rivero, diputado por Asturias y luego obispo de Zamora. Frente a la soberanía del pueblo, defendió la tesis tomista del origen divino del poder. Negó, además, la eficacia histórica de aquel principio, "germen fecundo de males y desgracias para el pueblo, únicamente ha servido de pretexto en las naciones para encender la tea de la discordia». Se opuso igualmente a la autodeterminación institucional, es decir, a la posibilidad de que los electores mudaran la forma de gobierno, "sistema que desquicia los fundamentos de la sociedad y está en contradicción con los verdaderos y esenciales principios del Derecho Público». Entendía la Monarquía como una institución permanente e inmutable. Combatió el unicameralismo democrático e hizo una defensa a ultranza de las Cortes estamentales con sus brazos nobiliario y eclesiástico. Defendió la aristocracia de sangre y al clero de los ataques igualitarios y laicistas. Votó contra la abolición del Santo Oficio, contra las medidas desamortizadoras; y, en general, contra la filosofía liberal y las corrientes ilustradas ${ }^{7}$.

Fuera de las Cortes gaditanas, el más célebre crítico tradicional de las reformas liberales fue el Padre Francisco de Alvarado, más conocido por el sobrenombre de «El Filósofo Rancio», maestro en el convento dominicano de San Pablo de Sevilla y autor de unas célebres Cartas críticas, en las que expone su sistema de gobierno y su oposición a los planteamientos liberales. Frente a la Constitución política, Alvarado reafirma la constitución tradicional, que considera recogida en las Partidas, consistente en una Monarquía templada por Cortes estamentales, que voten las leyes y consientan los impuestos. En ese régi-

\footnotetext{
5 VARELA, Joaquín: La teoría del Estado en los orígenes del constitucionalismo bispánico (Las Cortes de Cádiz), Madrid, 1983, páginas, 19-20 y ss.

6 Ibidem, páginas 425-426.

7 Vid. Cuenca Toribio, Juan Manuel: Don Pedro de Inguanzo y Rivero (1764-1836). Último primado del Antiguo Régimen, Pamplona, 1965, páginas 77-78, 80-81 y ss.
} 
men, la facultad de dictar leyes descansa en el monarca; pero con las limitaciones de la representación estamental, de los fueros y de la religión católica. Alvarado hizo igualmente una defensa sin fisuras de la Inquisición, atacando todos los argumentos en su contra defendidos por los liberales e ilustrados, con especial referencia a los planteamientos de Argüelles ${ }^{8}$. Muerto en 1814, Alvarado disfrutó de una longeva fama póstuma entre los defensores del tradicionalismo ideológico: Francisco Javier Caminero, Menéndez Pelayo, los padres Getino y Gafo, e incluso conservadores liberales como Silvela le consideraron un gran filósofo y doctrinario político. La redacción de El Siglo Futuro, órgano del Partido Integrista de Nocedal, estaba presidida por el retrato del dominico. En 1934, José María Pemán le hizo protagonista de su obra teatral Cuando las Cortes de Cádiz, y en 1941 se hizo una antología de sus escritos?

Tan importante o más que esta labor crítica fue la tarea propagandística y socializadora llevada a cabo por el clero a lo largo de la guerra de la Independencia. El hecho no era nuevo. El clero había participado decisivamente en la legitimación de la guerra contra la Convención. Ejemplo arquetípico de esta posición fue el opúsculo de Fray Diego de Cádiz, El soldado católico en guerras de religión (1794). Esta tendencia se agudizó a lo largo de la guerra contra Napoleón. Son innumerables los textos de sacerdotes que incitan a la lucha contra el francés «por la Religión». Se actualizó el santiaguismo y la apelación a las advocaciones españolas a la Virgen, como la del Pilar. Son constantes los paralelos veterotestamentarios: los españoles eran los macabeos, mientras que los franceses están representados por las figuras más aborrecidas de la historia de Israel. La reacción de los clérigos ante las doctrinas liberales fue tan virulenta como inequívoca. El liberalismo era «espíritu de libertinaje y disolución». Se ataca a las «sectas francmasonas, ateísta y materialista». E igualmente a la prensa liberalizante, "peste de la sociedad, polilla del Estado y escándalo de nuestra Santa Religión»" ${ }^{10}$.

No es extraño, pues, que la inmensa mayoría de los clérigos recibiera con inusitado alborozo la restauración del régimen absoluto por Fernando VII. Para algunos sacerdotes, significó nada menos que el retorno de la «Monarquía hebrea» ${ }^{11}$. En la legitimación del absolutismo fernandino tuvo singular importancia el célebre Manifiesto de los Persas, de 1814, suscrito por sesenta y nueve diputados realistas, encabezados por el Marqués de Mataflorida; y en el que se criticaba la obra de las Cortes de Cádiz, su convocatoria y la Constitución de 1812, cuya declaración de soberanía nacional era calificada como «despojo de

8 Las Cartas inéditas del Filósofo Rancio, Madrid, 1915, páginas 82, 120-121, 425-426 y ss.

9 Vid. Diz-LoIs, María Cristina: «Fray Francisco de Alvarado y sus Cartas Críticas», en Estudios sobre las Cortes de Cádiz, Pamplona, 1967, páginas 123-199. HERrERO, Javier: Los orígenes del pensamiento reaccionario español, Madrid, 1971, páginas, 267 y ss.

10 Vid. MARTínez AlBIACH, Alfredo: Religiosidad bispana y sociedad borbónica, Burgos, 1969, páginas 81-98, 112-129 y ss. PORTERO, José Antonio: Púlpito e ideología en la España del siglo XIX, Zaragoza, 1978, páginas, 62-73 y ss.

11 Ibidem, páginas 465 y ss.

Hispania, LXI/1, núm. 207 (2001) 99-142 
la autoridad real sobre que la Monarquía española está fundada, y cuyos religiosos vasallos habían jurado»; y lo mismo cabía decir de la libertad de prensa, "perjudicial para una nación pundorosa, y, además, subversiva en las Américas». Para los firmantes, la Constitución de 1812 era revolucionaria; una mera copia de la francesa, sin tener en cuenta la "constitución tradicional», susceptible de reforma. En el fondo, lo que se pedía era la restauración del Antiguo Régimen, con algunas reformas en los ámbitos de la administración, la justicia y las rentas del Estado ${ }^{12}$.

No hay que olvidar que a todo ello contestó Fernando VII con el famoso decreto del 4 de mayo, aceptando sus proposiciones.

A nivel ideológico, la reacción fernandina tuvo sus representantes en figuras como Atilano Dehaxo Solórzano, José Clemente Carnicero, Francisco Puigserver y, sobre todo, en Rafael Vélez, autor, entre otras obras, de Preservativo contra la irreligión y Apología del Trono y del Altar. Ambas obras suponen una crítica radical de la Ilustración y del liberalismo, unidos en su lucha contra el catolicismo. Vélez atribuye al filosofismo remotos orígenes que van desde Simón el Mago hasta Napoleón. En ese sentido, la obra de las Cortes de Cádiz supuso una traición a la lucha del pueblo español contra el francés; pues llevaba consigo «sus ideas de ilustración y sus planes de reforma». Vélez defiende la soberanía real y consideraba como germen de discordia la de los pueblos. El único derecho de éstos es representar, pedir y suplicar, a través de las Cortes. Los reyes ejercen un poder paterno, como los sucesores de los primeros padres ${ }^{13}$.

Con todo, la empresa doctrinal más importante de la época fernandina fue la publicación, entre 1826 y 1829 , de La Biblioteca de Religión, en cuya organización intervino el Cardenal Inguanzo, ahora arzobispo de Toledo. Su objetivo era, ante todo, «cooperar del modo posible al desempeño del cargo pastoral con el desengaño de los seducidos por los impíos y la lectura de los malos libros, como un preservativo para los débiles y como una obra que comunicando nuevas luces a los sabios las emplearan en beneficio de sus semejantes». La religión católica era, en fin, «el norte fijo de las sociedades morigeradas, y el verdadero barómetro de su grandeza y elevación $»^{14}$. A lo largo de sus tres años de existencia, la Biblioteca tradujo obras de Lamennais, Feller, Bonald, Maistre, etc.

No obstante, la reacción fernandina y su posterior desarrollo, en particular los continuos equilibrios que el monarca hubo de establecer a lo largo de su

12 Diz-Lois, María Cristina: El Manifiesto de 1814, Pamplona, 1967, páginas 66 y ss. Murillo Ferrol, Francisco: «El Manifiesto de los Persas y los orígenes del liberalismo español», en Ensayos sobre sociedad y política. I, Barcelona, 1987, páginas 195 y ss.

13 DE Velez, Rafael: Preservativo contra la irreligión o los planes de la filosofía contra la Religión y el Estado realizadas por la Francia para subyugar la Europa seguido por Napoleón en la conquista de España y dado a la luz por algunos de nuestros sabios en perjuicio de nuestra Patria, Cádiz, 1812, páginas, 10 y ss. Apología del Trono y del Altar, Madrid, 1818, tomo I, páginas 48, 328-330 y 475.

14 «Discurso Preliminar», en Biblioteca de Religión, o sea colección de obras contra la incredulidad y errores de estos últimos tiempos, Madrid, 1826, tomo I, páginas VI y IX. 
reinado, no dejaron satisfechos a todos los sectores antiliberales. Durante el llamado «Trienio Liberal» las conspiraciones absolutistas proliferaron. Y sus éxitos más notables se produjeron en Cataluña, donde en el verano de 1822 los absolutistas controlaron la zona norte, e instalaron una Regencia en Seo de Urgel, integrada por el Marqués de Mataflorida, Jaime Creus y el barón de Eroles. La Regencia publicó tres manifiestos, en los que se criticaba la labor de los liberales y se propugnaba el régimen tradicional, católico, monárquico y foral ${ }^{15}$. No muy diferente fue el pensamiento de los llamados «Agraviados», cuya sublevación cuatro años después tuvo tanta amplitud que el propio Fernando VII hubo de trasladarse a Cataluña para dominarla: «Viva la Religión, viva el Rey absoluto, viva la Inquisición, muera la Policía, muera el Masonismo y toda secta oculta» ${ }^{16}$.

El fracaso de estas insurrecciones llevó a los sectores absolutistas a la estrategia de intimidación a Fernando, mediante la conspiración en la Corte. Pero la nueva reina, María Cristina, tuvo una heredera; y el gobierno hizo publicar la Pragmática Sanción de 1789, que restableció los viejos usos sucesorios y desvaneció las esperanzas de que el hermano de Fernando, Carlos, ídolo de los absolutistas, subiera al trono. Poco a poco, se fue preparando lo que vino en llamarse «carlismo», y que llegaría a convertirse en uno de los ejes de la vida política española de la época.

\section{LA ESPAÑA ISABELINA: TRADICIONALISMO CARLISTA Y CONSERVADURISMO AUTORITARIO}

Con frecuencia, tiende a identificarse al carlismo con el conjunto del pensamiento antiliberal de la época isabelina. No obstante, la realidad histórica resulta distinta. El carlismo no fue, en ese sentido, más que uno de los antiliberalismos posibles, cuya concreción ideológica posterior estuvo, de hecho, muy influida por pensadores afines al partido moderado o próximos a éste. No en vano, puede hablarse de un «tradicionalismo isabelino» - igualmente denominado "conservadurismo autoritario» o "neocatolicismo»-, en el que estarían agrupadas figuras como Donoso Cortés, Jaime Balmes, Juan Bravo Murillo, etc.; y que unían su profundo antiliberalismo al reconocimiento de la legitimidad dinástica encarnada en Isabel II ${ }^{17}$.

\footnotetext{
15 Vid. MARRERO, Vicente: El Tradicionalismo Español del siglo XIX, Madrid, 1955 , páginas 69 y ss.

16 Vid. Torras, Jaime: La guerra de los Agraviados, Barcelona, 1967, páginas 15 y 199.

17 Vid. CÁnOvas SánChez, Francisco: El Partido Moderado, Madrid, 1982, páginas 125 y ss. Marqués de Rozalejo: Cheste o todo un siglo. El Isabelino Tradicionalista, Madrid, 1935. Alsina RoCA, Jose María: El tradicionalismo filosófico en España, Barcelona, 1985. URIGÜEN, Begoña: Orígenes y evolución de la derecha española: el neocatolicismo, Madrid, 1988. MARCuELLO, Juan Ignacio: «Sistema constitucional, práctica parlamentaria y alternativas conservadoras en el liberalismo isabelino», en Hispania, nº 183, 1993, páginas 237 y ss.

Hispania, LXI/1, núm. 207 (2001) 99-142
} 
El carlismo careció de toda relevancia intelectual. En un principio, los partidarios de Don Carlos, en cuyas bases sociales existía un claro predominio de los sectores agrarios, campesinos y comunales, pudieron sostenerse a través de tradiciones consuetudinarias, en cierto modo preconscientes; y en su seno, por lo tanto, la reflexión ideológica y teórica tuvo una importancia muy secundaria $^{18}$. En ese sentido, el carlismo puede ser encarnado en un estilo de pensamiento tradicionalista que se aproxima a lo que Mannheim llama «natural», es decir, adherido a «normas vegetativas y a viejos modos de vida ligados a elementos mágicos de conciencia» ${ }^{19}$. De 1833 a 1845, el carlismo, bajo la dirección de Carlos V, se movió, por ello, dentro de unos principios sumamente vagos, genéricos y abstractos, herederos, al menos en parte, de los planteamientos «realistas» gaditanos y de los apostólicos y «agraviados» del reinado de Fernando VII ${ }^{20}$.

Carlos V no contó, en ese sentido, con ningún intelectual de talla. Dentro de esta común mediocridad, destacan Fray Magín Ferrer y Vicente Pou, cuyo modelo político-institucional seguía siendo el del "Antiguo Régimen»: Monarquía absoluta y hereditaria, Consejo Real, Cortes estamentales, sistema foral, confesionalidad católica, etc ${ }^{21}$.

Sin embargo, el carlismo, como fuerza social y política de envergadura, tendió lógicamente a contrarrestar las realizaciones del liberalismo, suponiendo, de hecho, un importante freno a la consolidación de sus reformas; lo que, en gran medida, determinó la asunción por parte de un Estado liberal dirigido por los conservadores de ciertos postulados insertos en los supuestos con que se identificaba su antagonista. Ello se tradujo, durante la década moderada, en una política de ennoblecimiento de las élites, el aumento y el fortalecimiento de las prerrogativas regias y de la influencia del estamento eclesiástico a través del Concordato de $1851^{22}$. Y es que la guerra civil finalizó, de hecho, con un pacto, el de Vergara, que fue algo más que un pacto militar entre las fuerzas contendientes. Tras ese pacto - gracias al cual el partido moderado se incrementó con muchos de los carlistas de la facción transigente de Maroto-, y

18 WILHELMSEN, Alexandra: La formación del pensamiento político del carlismo (1810-1875), Madrid, 1995, páginas 184 y ss.

19 MANNHEIM, Karl: Ideología y utopía, página 107.

20 Vid. Madariaga Orbea, Juan y TAmayo ERrazQuin, José: «Una lectura de la primera guerra carlista: Los editoriales de la Gaceta Oficial y el Boletín de Navarra y Provincias Vascongadas", en Hispania, $\mathrm{n}^{\circ}$ 1.90, 1981, paginas 149 y ss.

${ }_{21}$ WILHELMSEN, Alexandra: «Magín Ferrer, pensador carlista renovador olvidado», en Estudios de Historia Moderna y Contemporánea. Homenaje a Federico Suárez Verdeguer, Madrid, 1991, páginas 401-490. «Pou, carlista temprano», en Razón Española, n 55, septiembre-octubre 1992, páginas 101 y ss.

${ }^{22}$ ARÓSTEGUI, Julio: «El carlismo en la dinámica de los movimientos liberales españoles. Formación de un modelo", en Actas de las Primeras Jornadas de Metodología Aplicadas a las Ciencias Sociales, Santiago de Compostela, 1975, tomo IV, páginas 225 y ss. CANAL, Jordi: El Carlismo. Madrid, 2000.

Hispania, LXI/1, núm. 207 (2001) 99-142 
después de la fallida experiencia esparterista, el moderantismo se aprestó a construir el Estado y la sociedad a su medida, cuidándose de conciliar los nuevos y los viejos intereses.

A la altura de los años cuarenta, la defensa cerrada e incondicional del «Antiguo Régimen» había sido superada por la consolidación del Estado liberal en su versión conservadora. Y los tradicionalistas más conscientes iban a dar un nuevo carácter a su programa político, aceptando las nuevas realidades sociales y suministrando argumentos restauradores a los sectores sociales hegemónicos, frente a los contenidos del liberalismo democrático. Se trataba, en el fondo, de recurrir a amasijos de elementos nuevos y viejos. No podía restablecerse ya in toto el pasado: su proyecto iba a implicar más bien un nuevo equilibrio entre las nuevas y viejas fuerzas sociales. No era tanto una involución como una restauración. Así, la tradición teológico-politica fue capaz de renovar sus contenidos y adaptarse a las nuevas situaciones.

En ese sentido, resulta esencial la figura de Juan Donoso Cortés, en quien podemos ver al representante más radical del conservadurismo autoritario español. Pocas figuras de nuestra historia intelectual contemporánea han suscitado el interés de historiadores y pensadores políticos extranjeros como Donoso. Es uno de los pensadores políticos a los que la historia actualiza periódicamente. Sus discursos de 1848 llegaron, en palabras de Carl Schmitt, «a fascinar al Continente europeo» ${ }^{23}$.

Suele dividirse la vida y la obra de Donoso en dos grandes etapas: la primera racionalista y liberal; fideísta y autoritaria la segunda. Sin embargo, en Donoso las rupturas nunca son totales; y bajo la aparente discontinuidad fluyen profundas continuidades, tanto en los temas como en los planteamientos. Su espíritu elitista y antidemocrático, la búsqueda de elementos de cohesión para una sociedad en crisis permanente, el recurso a la dictadura, el diálogo continuo con los pensadores tradicionalistas son constantes de su pensamiento. El permanente conservadurismo donosiano fue agudizándose tras el efecto que produjeren en su mente los sucesos de 1848, en los que vio, como Tocqueville, el primer intento de revolución socialista. A su modo de ver, la nueva situación exigía medidas excepcionales. No era solo la dictadura del «hombre fuerte e inteligente», sino la «disolución de todos los partidos antiguos y la formación de un nuevo", capaz de aglutinar en su seno los intereses de la Monarquía, la Iglesia, el Ejército y la propiedad. En aquellos momentos, el orden social descansaba sobre la acción conjunta de sacerdotes y militares, figuras tan necesarias como complementarias. La crisis contemporánea no podía solventarse, a su juicio, más que con el retorno a las viejas certezas católicas. Sólo la autoridad emanada de la religión podía esclarecer la dominación establecida en el orden social y; por ello, hacerla inmune a la crítica. Las posiciones políticas derivaban, en el fondo, de las actitudes ante la figura de Dios, en las que se perfilaban las

\footnotetext{
23 SCHMITT, Carl: Interpretación europea de Donoso Cortés, Madrid, 1952, páginas 122 y ss.
} 
dos fases sucesivas de la civilización: la positiva y la negativa. En la fase positiva, gobierna un Dios providente; en la negativa, se producen tres negaciones sucesivas: el deísmo, que equivale a liberalismo, al negar la providencia divina; el panteísmo, que supone la democracia, que niega la existencia de un Dios transcendente al mundo; y el ateísmo, que equivale a socialismo y anarquismo, al negar la existencia de Dios. En el fondo, era la razón crítica la causa del caos social. De la autonomía de la razón surgía el liberalismo, cuyas doctrinas preparaban el camino al socialismo. El liberalismo carecía de una estructura de carácter teológico, lo que le hacia vulnerable al socialismo, que era una "teología satánica»; $y$, en ese sentido, su influencia sólo podía ser contrarrestada por el catolicis$\mathrm{mo}^{24}$. A pesar de sus exageraciones fideístas, Donoso resultó ser, en la práctica, un agudo analista político y, en ocasiones, un sagaz crítico del proyecto de la modernidad, cuyos principios iban a marcar durante mucho tiempo, no sólo la perspectiva ideológica de los sectores políticos antiliberales, sino incluso los de la derecha conservadora: su influencia en Cánovas, por ejemplo, pese a las apariencias, resulta evidente. No en vano, Carl Schmitt le consideró más actual que Joseph de Maistre, al romper, de hecho, con la legitimidad monárquica y convertirse en heraldo de la dictadura y el decisionismo ${ }^{25}$. Planteamiento éste, por cierto, muy criticado por los donosianos españoles, que siempre vieron en él a un monárquico y a un iusnaturalista ${ }^{26}$.

Más sereno y menos radical, Jaime Balmes fue el otro gigante intelectual del conservadurismo autoritario español del ochocientos. Pero, en realidad, Balmes tiene una sola cosa en común con Donoso: la causa católica y antiliberal que defienden. Miembro del estamento más castigado por la revolución liberal, su proyecto político y filosófico tuvo como objetivo la restauración del papel hegemónico de la Iglesia católica en la sociedad española. En ese sentido, sus fórmulas políticas se caracterizan por un intento de transacción entre el tradicionalismo y el liberalismo moderado; es decir, «armonizar la sociedad nueva con la sociedad vieja». Inspirador ideológico de la facción más conservadora del partido moderado, la de los "tradicionalistas isabelinos», capitaneada por el Marqués de Viluma, Balmes, que nunca fue carlista, pretendió atraerse a los partidarios del Pretendiente, auspiciando la unión dinástica, a través del matrimonio del heredero de Don Carlos con Isabel II. En ese sentido, podemos considerar a Balmes un pensador político ecléctico. Su punto de partida era el fracaso de la revolución liberal española, mera copia de la francesa y, por lo tanto, incapaz de constituirse en algo sólido y duradero. Su victoria había sido consecuencia de los trastornos provocados por la agresión francesa, aprovechados por una minoría audaz que supo hacerse con los resortes del poder. La labor de las Cortes gadi-

${ }^{24}$ Donoso Cortés, Juan: «Ensayo sobre el catolicismo, el liberalismo y el socialismo», en Obras Completas, Madrid, 1970, tomo II, páginas 643 y ss.

${ }^{25}$ SCHMITT, op. cit., página 132.

26 Vid. González Cuevas, Pedro Carlos: «Carl Schmitt en España», en Dalmacio Negro PAVÓN (dir.), Estudios sobre Carl Schmitt, Madrid, 1995, páginas 231 y ss. 
tanas fue una traición a los principios por los que había luchado el grueso de la población española a lo largo de la Guerra de la Independencia, es decir, «el Rey y la Religión». Así pues, la sociedad española se encontraba en un claro período de «transición». El carlismo seguía siendo «el depositario del antiguo espíritu nacional»; mientras que el liberalismo contaba con la fuerza de la propiedad y la del Ejército. El militarismo era, a ese respecto, un producto de la incapacidad de las instituciones liberales para consolidar un poder civil efectivo ${ }^{27}$.

La unión dinástica implicaba una transformación del sistema político en un sentido tradicional. Debía ser la expresión del auténtico "pensamiento de la Nación», arraigado en lo profundo de la comunidad y configurado en «su catolicismo, en su monarquía y demás leyes fundamentales». La fórmula balmesiana era un sistema bicameral, con una cámara alta en la que estuvieran representados los poderes estamentales: arzobispos y obispos natos, nombrados por el rey; Grandes de España, propietarios agrarios, alta burguesía. En la cámara baja, no debía entrar nadie que no disfrutara de un renta en bienes raíces de cuando menos doscientos mil reales. No obstante, la clave de su proyecto se encontraba en la Monarquía y la Iglesia. La Monarquía balmesiana era una auténtica autocracia, en la que el rey ejerce todos los poderes. A la Iglesia, por su parte, le correspondía la función legitimadora del sistema social y político; era la única institución española cuya voz podía oírse en el conjunto de la nación; y, por ello, como contrapartida a los daños de la desamortización, debía reconocérsele el derecho a disponer de bienes, la subvención a sus organizaciones y a la enseñanza confesional ${ }^{28}$.

Mediante la constitución de este sistema político, Balmes pretendía crear un régimen político "puramente español», que desembocaría necesariamente en la fusión en un solo partido de los auténticos defensores del catolicismo y la monarquía; lo cual tendría como consecuencia el aniquilamiento de los partidos liberales: el progresismo sería declarado fuera de la ley, al igual que «una pequeña fracción del moderado» ${ }^{29}$. Como es sabido, los planes de Balmes fracasaron. La unión dinástica fue rechazada tanto por liberales como por la mayoría de los carlistas. Pero ello no significa que su proyecto político, lo mismo que el conjunto de su obra, careciese de influencia. En gran medida, la práctica política cotidiana del sector más influyente de los moderados, el capitaneado por Narváez, estuvo más conforme con las pautas del conservadurismo autoritario balmesiano y donosiano que con los cánones del constitucionalismo liberal ${ }^{30}$.

Y no faltaron en el seno del moderantismo intentos de reforma en sentido autoritario de la ya de por sí escasamente liberal Constitución de 1845. El más célebre fue el auspiciado por Juan Bravo Murillo, representante del conserva-

27 Balmes, Jaime: Obras Completas, Madrid, 1950, tomo VI, páginas 33, 39, 224 y 71-72 y tomo VII, páginas 568 y ss.

28 BALMES: Obras Completas, tomo VI, páginas 638 y ss.

29 Ibidem, páginas 735 y ss.

30 Vid. MARCUELLO, Juan Ignacio: «Sistema constitucional, práctica parlamentaria y alternativas conservadoras en el liberalismo isabelino», en Hispania, $\mathbf{n}^{\circ} 183,1993$, páginas 237 y ss. 
durismo autoritario, amigo de Donoso Cortés; y que llevó a término una de las reivindicaciones más transcedentales de los sectores católicos y tradicionalistas, como fue el Concordato de 1851, en el que se reconocía el catolicismo como única religión de la nación española. No obstante, Bravo Murillo es conocido, aparte de por su sobresaliente obra hacendística, por su proyecto constitucional nacido al calor del golpe de Estado francés de 1851. La justificación doctrinal más explícita de éste parece encontrarse en su opúsculo De la soberanía, donde defiende la soberanía popular, pero entiende que por sus actos positivos no es realizable. El mismo sufragio universal no pasa de ficción. En realidad, el único origen de la soberanía de derecho es el asentimiento tácito de los pueblos ${ }^{31}$. El proyecto constitucional era muy breve y no contemplaba los derechos ciudadanos, que pasaban a una ley orgánica. Su objetivo era «dejar más libre y expeditiva la autoridad real». Concedía al Rey y a las Cortes, conjunta o separadamente, la iniciativa de proposición de leyes, y a ambos elementos en conjunto la posibilidad de hacerlas; pero en casos de urgencia el monarca, y en concreto el gobierno, podría gobernar por decreto. Mayor importancia tenía, sin embargo, el carácter que se pretendió dar al Senado, pieza esencial del proyecto. Sus miembros lo serían por derecho propio; unos por nobleza hereditaria, con vinculación inalienable de los bienes raíces - lo que suponía la restauración de los mayorazgos - ; otros por méritos en el ejercicio de la función pública, como eclesiásticos, militares o magistrados, cuyo nombramiento correspondía al monarca. El Congreso estaría formado por diputados representantes de los distritos de la nación; su número sería de 171 . Y las discusiones se harían a puerta cerrada ${ }^{32}$.

Bravo Murillo buscó apoyos para su proyecto en la reina, la Corte y la Iglesia; pero contó con la oposición de la mayoría del partido moderado, de los progresistas y de los militares, e incluso de su sector de la aristocracia. Lo cual significó el final de su carrera política.

Al mismo tiempo, el tradicionalismo ideológico tuvo, a lo largo del período isabelino, un amplio desarrollo, sobre todo en Cataluña y Mallorca, donde destacó un grupo perfectamente definido de apologistas católicos reunidos por Joaquín Roca y Cornet, a partir de 1837, en la revista barcelonesa La Religión. Roca y Cornet tradujo los Anales de la Filosofía Cristiana, de Bonnety; y en sus artículos es muy patente la influencia de Bonald. Y José Ferrer y Subirana, antiguo condiscípulo de Balmes, traduce y prologa a Bonald 33 . Con Roca y Cornet colaboran Manuel de Cabanyes y los mallorquines Tomás Aguiló, y, sobre todo, José María Quadrado, el más interesante, sin duda, de todos ellos; competente historiador y

31 Bravo Murillo, Juan: Política y Administración en la España isabelina, Madrid, 1972, páginas 84 y ss.

32 PÉRez Serrano, Nicolas: «Bravo Murillo, hombre político», en Primer Centenario de Don Juan Bravo Murillo, Madrid, 1952, páginas 25 y ss.

33 ALSINA ROCA Jose María: El tradicionalismo filosófico en España. Su génesis en la generación romántica catalana, Barcelona, 1985, páginas 149 y ss. 
apologista, colaboró con Balmes en sus campañas de El Conciliador y El Pensamiento de la Nación, favorables al proyecto de unión dinástica ${ }^{34}$.

Herederos de los planteamientos políticos de Donoso y Balmes fueron igualmente los llamados «neocatólicos» de Madrid. Pero se trata de pensadores de menor talla intelectual que sus maestros. La obra de estos escritores católicos se reduce a organizar un influyente frente polémico contra los krausistas; y tienen órganos de expresión propios, como El Pensamiento Español, fundado en 1860. Apologética y política se reúnen en ellos estrechamente. Su acción se extiende, sobre todo, al Parlamento y a la prensa; menos en la Universidad. En el Parlamento están representados por Cándido Nocedal y Antonio Aparisi y Guijarro; en la prensa por Gabino Tejado - amigo personal y discípulo de Donoso-, Eduardo González Pedroso - director del célebre periódico El Padre Cobos - y Francisco Navarro Ledesma; y en la Universidad por Ortí y Lara. Objeto preferido de sus campañas fueron los krausistas, a los que acusaron de panteístas y anticatólicos. Especialmente significativa fue, en ese sentido, su campaña de los «textos vivos» desde las columnas de El Pensamiento Español. Los «textos vivos» eran los profesores universitarios no católicos, preferentemente krausistas, así como sus obras los «textos muertos». La campaña tuvo su resultado apetecido; pues por decreto del gobierno moderado el profesorado se vio obligado a prestar un doble juramento de fidelidad al catolicismo y a la monarquía 35 .

En el campo carlista, durante el período de Carlos VI cambiaron algunos principios ideológicos y la orientación política, todo ello a nivel de élite dirigente; pero en modo alguno se consiguió articular una doctrina precisa y coherente. Los documentos del Pretendiente, bajo la inspiración balmesiana, intentaron una aproximación a las bases sociales del Estado isabelino ${ }^{36}$. La pronta muerte del Conde de Montemolín frustró aquellas pretensiones. Y la extraña proclividad liberal de Don Juan, su heredero, erigió en guardiana de las esencias carlistas a la viuda de Carlos V, la Princesa de Beira, cuya Carta a los espanoles, publicada en 1864, bajo la influencia del obispo Caixal y de Pedro de la $\mathrm{Hoz}^{37}$, insistió en la tajante oposición al liberalismo, la defensa del catolicismo y de una Monarquía de derecho divino limitada por las leyes fundamentales del reino. La Carta definía como elemento axial de la Monarquía el principio de las dos legitimidades, la de origen y la de ejercicio. Era la respuesta a la actitud proliberal de Don Juan. La legitimidad de origen no quería decir legitimidad sin más. Legalidad y legitimidad debían coincidir; pero a veces lo legal por ser

\footnotetext{
${ }^{34}$ ISERN, Damián: Quadrado y sus obras, Madrid, 1896. SABATER, Gaspar: José Maria Quadrado, Palma de Mallorca, 1967.

35 URigüEn, Begoña: Orígenes y evolución de la derecha española: el neocatolicismo, Madrid, 1988, páginas 291 y ss.

36 WILHELMSEN, Alexandra: La formación..., páginas 353 y ss.

37 Wilhelmsen, Alexandra: "Pedro de la Hoz, crítico del parlamentarismo», en Razonalismo. Homenaje a Fernández de la Mora, Madrid, 1995, páginas 301 y ss.
}

Hispania, LXI/1, núm. 207 (2001) 99-142 
injusto no era legítimo. La legitimidad de ejercicio suponía la fidelidad a las exigencias institucionales, la lealtad a todo lo que esencialmente supone la legitimidad de origen, de tal forma que si la legitimidad de ejercicio fallaba, se borra la de origen ${ }^{38}$.

\section{DEL SEXENiO A LA RESTAURACIÓN}

El estallido de la «Gloriosa» en septiembre de 1868 supuso, de facto, un refuerzo para las tendencias políticas de extrema derecha, sobre todo a las agrupadas en torno al tradicionalismo carlista. La caída de Isabel II tuvo importantes consecuencias a nivel político y a nivel simbólico. No fue solamente la instauración del sufragio universal, adelantándose a la mayoría de los países europeos, o la aparición de la I Internacional, o la renovada influencia de los krausistas en la Universidad; fueron, sobre todo, las innovaciones de carácter religioso, como la promulgación de la libertad de cultos, o la expulsión de los jesuitas, las que más transcendencia tuvieron en el conjunto de la opinión pública de la época. La ofensiva anticlerical coincidió, además, con un endurecimiento de las posiciones políticas y doctrinales de la Iglesia católica, que tuvo su máximo exponente en el célebre Syllabus y luego en el Concilio Vaticano I.

Todo lo cual hizo renacer al carlismo como movimiento político de envergadura, bajo la dirección de Carlos VII, Duque de Madrid. A raíz de la caída de Isabel II, el Pretendiente recibió nuevas e importantes adhesiones provenientes no sólo del campesinado, sino de sectores burgueses urbanos, del clero y, sobre todo, de los «neocatólicos», cuyos líderes más significativos, Nocedal, Aparisi, Navarro Villoslada, Tejado, etc., se pasaron, con armas y bagajes, a las filas carlistas.

Este nuevo auge del carlismo tuvo su manifestación más elocuente en la proliferación de la publicística contrarrevolucionaria, de la que fueron testimonio El bombre que se necesita, de Navarro Villoslada; Don Carlos o el petróleo, de Vicente Manterola; o El Rey de España, de Aparisi y Guijarro. Igualmente, la prensa carlista conoció un apreciable incremento: unos ciento sesenta periódicos y revistas; y el número de folletos rebasaba los sesenta ${ }^{39}$.

No obstante, la innovación ideológica fue mínima. La crisis española no generó, a diferencia de lo ocurrido en Francia, una renovación del tradicionalismo y del conservadurismo en un sentido positivista y secularizado. España no tuvo, ni, por otra parte, pudo tener su Renan, su Taine o su Fustel de Coulanges. La razones de ello fueron, sobre todo, religiosas. Renan, por ejemplo, fue leído por los sectores liberales e izquierdistas de la época. Pero a los ojos de

\footnotetext{
38 Inserta en MARRERO, Vicente: El Tradicionalismo..., páginas 240 y ss.

39 Extramiana, José: Historia de las guerras carlistas,. San Sebastián, 1979, tomo I, páginas 200 y ss.
} 
tradicionalistas y católicos era, ante todo, un apóstata, cuya Vida de Jesús no podía ser vista más que como una blasfemia ${ }^{40}$. En ese sentido, no existió posteriormente mención alguna a La reforma intelectual y moral, que tanto influyó en Charles Maurras y L'Action Française. Por otra parte, el positivismo se contempló por parte de católicos, conservadores y tradicionalistas como una filosofía inmanentista, atea e incluso revolucionaria; y no se tuvo en cuenta para nada sus indudables posibilidades contrarrevolucionarias ${ }^{41}$.

El pensador político afín al carlismo más reseñable fue el neocatólico Antonio Aparisi y Guijarro, quien durante el período isabelino se distinguió como un consumado orador y un sagaz e implacable crítico de las contradicciones del régimen liberal. En ese sentido, criticó el caciquismo, la ley de quintas, los proyectos desamortizadores de Madoz, etc. Previendo el estallido revolucionario, Aparisi calificó a Isabel II, en frase que llegó a hacerse célebre, "reina de los tristes destinos» ${ }^{42}$. Ya en el carlismo, a él se deben casi íntegramente los distintos manifiestos publicados por Carlos VII. De su producción ideológica, lo más reseñable es el proyecto de Constitución elaborado en julio de 1871 para que sirviera a la fusión entre alfonsinos y carlistas. En el proyecto, se establecían dos leyes fundamentales: la confesionalidad católica del Estado y la soberanía real. Y contemplaba la existencia de unas cortes corporativas y de un Consejo real que asesorara al monarca ${ }^{43}$.

Por su parte, Carlos VII prometió una «Ley Fundamental»; en la que se garantizaba «la unidad católica, símbolo de nuestras glorias, espíritu de nuestras leyes, bendito lazo de unión entre españoles»; concordato con la Santa Sede, cortes corporativas, descentralización, foralismo, protección de la industria nacional. E intentó dejar claro que no se restaurarían «antiguas instituciones», como la Inquisición ${ }^{44}$.

No obstante, el carlismo estuvo dividido en tendencias radicalmente disconformes a lo largo del Sexenio: legalistas e insurreccionalistas. Los primeros estaban representados, sobre todo, por los neocatólicos; los segundos por los viejos carlistas. Los neocatólicos pudieron mostrar lo acertado de su posición en las elecciones de 1869 y de 1871; pero tras la muerte de Aparisi al año siguiente y el fracaso electoral, la insurrección militar pareció a Don Carlos la única solución viable. La insurrección triunfó en Beramendi y Alpens, lo que permitió al Pretendiente retornar a España en julio de 1873, tomar Estella y hacer de

\footnotetext{
40 Vid. PÉREZ GUTIÉRREZ, Francisco: Renan en España (Religión, ética y política), Madrid, 1988, páginas 113 y ss.

${ }^{41}$ NUÑEZ RUIZ, Diego: La mentalidad positiva en España: desarrollo y crisis, Madrid, 1975, páginas 59 y ss.

42 Aparisi y Gujarro, Antonio: «El Rey de España», en En' defensa de la libertad, Madrid, 1957, páginas 268 y 338.

43 APARISI y GuiJARro, Antonio: Obras Completas, Madrid, 1874, tomo III, páginas 373 y ss.

${ }^{44}$ Inserto en MARRERO, Vicente: El Tradicionalismo..., páginas 391 y ss
} 
ella su capital. Ello le permitió forjar un embrión de Estado y poner en práctica sus proyectos políticos ${ }^{45}$.

Los moderados autoritarios que, como Bravo Murillo, permanecieron fieles a Isabel II, fundaron en 1872, con el apoyo de importantes miembros de la aristocracia tradicional y de la alta burguesía de negocios, La Defensa de la Sociedad, revista que intentó aglutinar al conjunto de la derecha y de la extrema derecha frente a la amenaza encarnada en los proyectos del liberalismo radical, de la democracia y de la I Internacional. Entre sus colaboradores, hubo carlistas, como Aparisi y Nocedal; moderados, como Barzanallana y Pidal; conservadores liberales, como Cánovas del Castillo o el Marqués de Molins; y también fue significativa la presencia del clero: Zeferino González, Antolín Monescillo, Francisco Javier Caminero o el Padre Coloma. Los principios ideológicos de la revista fueron los de «Religión, Familia, Trabajo, Patria y Propiedad». En ese sentido, Joaquín Sánchez de Toca defendió, en una línea muy próxima a Bonald, la propiedad agraria como fuente de estabilidad política y social ${ }^{46}$. Zeferino González y Caminero criticaron el positivismo y el krausismo como filosofías ateas, revolucionarias y antinacionales ${ }^{47}$. Ignacio María de Ferrán se mostró partidario de una Monarquía tradicional basada en el catolicismo y en el principio del "honor", e incompatible, por tanto, con la libertad de cultos, el sufragio universal y el liberalismo ${ }^{48}$. Carlos María Perier criticó el principio electivo y el sufragio universal, proponiendo en su lugar el familiar ${ }^{49}$.

Con respecto a la cuestión social, la revista defendió desde posturas abiertamente paternalistas, como las de Padre Coloma, hasta proyectos corporativos y reformistas, como los de algunos empresarios como Sallarés Pla y Muñoz Cerisola, afines a la perspectiva de Balmes ${ }^{50}$.

\section{El LARGO VERANO LIBERAL ... Y TRADICIONAL}

La Restauración de 1874, aunque no fue propiamente hablando una contrarrevolución, sí fue una reacción conservadora que, en sus primeros momen-

45 Vid. Montero DíAZ, Julio: El Estado carlista (1872-1876), Madrid, 1992.

46 «De la propiedad», en La Defensa de la Sociedad, n 174, 16-XII-1877, páginas 329 y ss.

47 GoNZÁLEZ, Zeferino: El positivismo materialista. Artículos insertos en la revista "La Defensa de la Sociedad», Madrid, 1872, páginas 7 y 38-40. «Estudios krausistas», La Defensa de la Sociedad, $\mathrm{n}^{\circ} 142$, 15-VIII-1876, páginas 195 y ss. 100-101.

48 «Del honor de las Monarquías», en La Defensa de la Sociedad, nº 134, 16-IV-1875, páginas

49 «De la soberanía y el sufragio universal», en La Defensa de la Sociedad , n 121, 1-X-1875, páginas $30-31$.

so «Pobres y ricos (Artículo para ricos)», en La Defensa de la Sociedad, n 6, 1-IV-1872, páginas 11 y ss. "Huelgas», en La Defensa de la Sociedad, n 169, 1-X-1877, páginas 43 y ss. «Los barrios obreros», en La Defensa de la Sociedad, $\mathrm{n}^{\circ} 118,16-\mathrm{VIII}-1875$, páginas 581 y ss.

Hispania, LXI/1, núm. 207 (2001) 99-142 
tos, anuló muchos de los logros sociales y políticos obtenidos durante el Sexenio. Su máximo artífice, Antonio Cánovas del Castillo, no perteneció a ninguna de las tradiciones de extrema derecha; era un conservador liberal, pero tampoco fue inmune a la influencia del tradicionalismo ideológico y de la neoescolástica. El conservadurismo liberal de Cánovas admitía de modo pragmático aquellas transformaciones políticas y sociales que parecían irreversibles; pero intentó conservar, al mismo tiempo, determinadas concepciones políticas y sociales tradicionales. Cánovas trató de conciliar historia y razón, pasado y presente, sociedad estamental y sociedad burguesa, Antiguo Régimen y liberalismo; y, en ese sentido, en la ideología de la Restauración «hay algo que - dirá Jesús Pabón- doctrinal e históricamente pertenece al Tradicionalismo» ${ }^{51}$.

Cánovas tuvo graves problemas con los sectores de extrema derecha, a causa de su proyecto de unión liberal y su iniciativa de tolerancia de cultos, plasmada, aunque de forma muy restringida, en el articulo 11 de la Constitución de 1876. Sin embargo, logró la integración de la Iglesia católica en el régimen, e hizo muchas concesiones a los católicos en materia social y de enseñanza. Gracias a ello, logró neutralizar durante algún tiempo a los sectores más agresivos de la extrema derecha. Pero estas concesiones contribuyeron a configurar un Estado dual. El Estado de la Restauración fue una mezcla de Estado constitucional, con amplias libertades de expresión y de asociación; y de Estado tradicional, donde la soberanía era compartida por el Rey y las Cortes, y en el que la influencia del Ejército, la Iglesia y la Corona resultaba determinante.

De esta forma, la Restauración supuso el comienzo, por emplear la expresión de George Steiner, de «un largo verano liberal», pero también tradicional, «un largo periodo de reacción y calma» ${ }^{52}$. La estrategia canovista contribuyó a dividir a los sectores políticos de extrema derecha; entre un sector posibilista, favorable al reconocimiento de la legitimidad del régimen y de colaborar en sus instituciones, cuya genealogía era fundamentalmente balmesiana; y un sector radical, irreductible, de ascendencia carlista, que posteriormente se fragmentaria aún más con la escisión integrista.

El sector posibilista estuvo políticamente capitaneado por Alejandro Pidal y Mon, líder de la llamada Unión Católica, que intentó renovar el proyecto balmesiano de unión dinástica y alianza con el carlismo, cuya ejecución se saldó finalmente en un rotundo fracaso ${ }^{53}$. Finalmente, Pidal y sus partidarios, al chocar con la absoluta enemistad de los carlistas, terminaron integrándose en el partido liberal-conservador de Cánovas. Este fracaso a nivel político no debe ocultar la importancia de este sector, donde se encuentran las figuras mas señe-

\footnotetext{
s1 PABÓN, Jesús: Cambó, 1876-1918, Barcelona, 1952, página 128.

52 STEINER, George: En el castillo de Barbazul. Aproximación a un nuevo concepto de cultura, Barcelona, 1992, páginas 22 y ss.

s3 Vid. MagaZ, José María: La Unión Católica (188l-1885), Roma,' 1990.
}

Hispania, LXI/1, núm. 207 (2001) 99-142 
ras de la cultura católica del momento. Pidal fue discípulo de Fray Zeferino González y Díaz Tuñón, principal representante español de la neoescolastica ${ }^{54}$.

El cardenal González no fue un reaccionario integral; y de acuerdo con los supuestos de la neoescolástica triunfante en el Concilio Vaticano I sometió a fuerte crítica los puntos más radicales del tradicionalismo filosófico, en particular el fideísmo, el pesimismo o la enemiga de la «razón natural». Aunque muy critico con los contenidos del proyecto de la modernidad, consideraba imposible un retorno a la etapa pre-moderna; como en el caso de Balmes, su posición fue ecléctica. Su programa político consistía en la restauración de la «Monarquía templada», "muy lejos de nuestras monarquías constitucionales, en que el rey reina y no gobierna», y en la crítica de la economía política liberal, centrada exclusivamente en el individuo, a la que contraponía la «economía política cristiana», basada en el «bienestar moral» de la comunidad"s.

Pidal tuvo ocasión de asistir a las lecciones de filosofía del dominico en el madrileño convento de la Pasión, junto a Eduardo Hinojosa y a Ortí y Lara. Pidal vio en Zeferino González al sucesor de Balmes y Donoso Cortés en el campo de la filosofía católica española ${ }^{56}$. Para el logro de su planes políticos, Pidal consiguió el apoyo de numerosos intelectuales católicos, como el Marqués de Vadillo, Damián Isern, Francisco Javier Caminero, Joaquín Sánchez de Toca, Eduardo Hinojosa, la condesa de Pardo Bazán, Marcelino Menéndez Pelayo, etc. Y ofreció a la Restauración alfonsina la neoescolástica como filosofía legitimadora. El neotomismo establecía la razón soberana de Dios y los límites de la razón humana, mediante la restauración de la metafísica. De esta forma, se superaba, a nivel especulativo, la crisis inaugurada por el racionalismo, cuyo principal efecto había sido la secularización de la filosofía y, por ende, de las sociedades. La metafísica tomista ofrecía, en ese sentido, la imagen de un mundo acabado y perfecto, sin contradicciones, como fruto y consecuencia de la voluntad suprema de Dios ${ }^{57}$.

No obstante, la principal figura intelectual de la Unión Católica fue el historiador Marcelino Menéndez Pelayo, en cuya voluminosa obra el conjunto de la derecha y de la extrema derecha española encontró la crítica más sistemática a los lugares comunes de la historiografía liberal. Lo que Taine y Fustel de Coulanges supuso para el nacionalismo integral maurrasiano lo fue Menéndez Pelayo para el conjunto de la derecha española. Formado en el tradicionalismo balmesiano, Menéndez Pelayo interpretó la historia de España como la actualización y autodespliegue del espíritu católico a lo largo de tiempo. La historia de España venía a ser una disputa permanente en favor del catolicismo frente a

${ }^{54}$ DíAZ De Cerio, Franco: Un Cardenal filósofo de la Historia, Roma, 1968.

ss GONZÁLEZ, Zeferino: Historia de la Filosofía, Madrid, 1884, tomo IV, páginas 372 y ss. Estudios sobre la Filosofía de Santo Tomás, Madrid, 1887, tomo III, páginas 405 y ss. «La economía política y el cristianismo", en Estudios científicos, filosóficos y sociales, Madrid, 1873, tomo II, páginas 9-10 y ss.

56 PIDAL, Alejandro: «El Padre Zeferino», en Discursos y artículos literarios, Madrid, 1887, páginas 287-288.

57 PIDAL, Alejandro: De la metafísica contra el naturalismo, Madrid, 1887, páginas 46 y ss. 
la heterodoxia, que se iba repitiendo en ciclos de ascenso y decadencia, según fuese o no la Iglesia católica quien dirigiera ideológicamente a la sociedad española. Y es que, en el fondo, español era sinónimo de católico. Ello le llevó a privilegiar los momentos históricos de unidad católica, como el de los Austrias; $y$, en consecuencia, a rechazar tanto el de los Borbones como el liberal. En ese sentido, exaltó a la Inquisición, al Filosofo Rancio, a Balmes y Donoso y a todos los apologistas católicos, como auténticos representantes del espíritu nacional, frente a los heterodoxos ${ }^{58}$.

Frente a este sector posibilista, iba a surgir una tendencia mucho más radical, que, con el tiempo, llegará a enemistarse con el propio Carlos VII, al que acusó de liberal. Fue lo que posteriormente vino en llamarse «integrismo»; y cuyo doctrinario más coherente fue el célebre presbítero Félix Sardá y Salvany, autor de El liberalismo es pecado, cuyo principal destinatario fue, en un principio, Alejandro Pidal. Desde la perspectiva teológico-política de este tradicionalista radical, liberalismo era sinónimo, en la práctica, de «ladrón», «blasfemo», «adúltero» y "criminal». Liberalismo era, en fin, racionalismo, capitalismo, espíritu burgués y anticatólico ${ }^{59}$.

La aparición del Partido Integrista, tras la escisión carlista de 1888, dio un tinte aún más radical al tradicionalismo. El programa del Integrismo se apoyaba, según la célebre Manifestación de Burgos de junio de 1889, obra de Ramón Nocedal, en los siguientes puntos: absoluto imperio de la fe católica «íntegra»; condena del liberalismo como "pecado»; negación de los «horrendos delirios que con el nombre de libertad de conciencia, de culto, de pensamiento y de imprenta, abrieron las puertas a todas las herejías y a todos los absurdos extranjeros»; descentralización regional y un cierto indiferentismo en materia de forma de gobierno ${ }^{60}$. El Integrismo no pudo competir intelectualmente con los miembros de la Unión Católica, ni políticamente con el carlismo; pero su espíritu impregnó durante mucho tiempo a un importante sector del clero y de la población católica española.

El conservadurismo autoritario y el tradicionalismo carlista recibieron un nuevo apoyo de la Iglesia católica, con la aparición de la encíclica Rerum Novarum, sobre todo por su condena del pensamiento político y social moderno - liberalismo, democracia y socialismo- y su rehabilitación de la concepción jerárquica de la sociedad y de los gremios ${ }^{61}$.

Al socaire de esta nueva coyuntura ideológica, el tradicionalismo carlista, libre de la rémora integrista, pudo renovar su proyecto político y su concepción

\footnotetext{
58 MenÉndez Pelayo, Marcelino: La Ciencia Española, Madrid, 1956 e Historia de los heterodoxos españoles, Madrid, 1968.

s9 SARDÁ Y SAlvany, Felix: El liberalismo es pecado, Madrid, s/f, páginas 8-9, 29-30 y ss.

60 NoCEDAl, Ramón: "Manifestación de la Prensa Tradicionalista», en Obras. Discursos, Madrid, 1907, tomo II, páginas, 1-62.

61 Vid. MONTERo GarCía, Feliciano: El primer catolicismo social y la Rerum Novarum en España Madrid, 1983.
}

Hispania, LXI/1, núm. 207 (2001) 99-142 
de la sociedad, gracias a las aportaciones de Enrique Gil y Robles, traductor de Stahl y crítico del positivismo jurídico y del krausismo. Para Gil y Robles, la sociedad era un entidad orgánica, dividida en clases, a cada una de las cuales correspondía una función determinada en el conjunto social; y también lo estaba en una serie de cuerpos intermedios entre el Estado y el individuo: la familia, la región, el gremio, el municipio, todos los cuales tienen derecho de «autarquía» —es decir, «derecho de propio e inmediato gobierno» frente al intervencionismo y el centralismo característico del Estado liberal- Consecuencia de ello es la doctrina de la «democracia cristiana», es decir, la atribución y el reconocimiento al pueblo, jerárquicamente organizado en clases y cuerpos, de la posición que le corresponde en el conjunto social. A través de unas Cortes corporativas, el pueblo comparte la soberanía social con el Rey, a quien corresponde la soberanía específicamente política ${ }^{62}$.

No obstante, el ideólogo por antonomasia del carlismo en aquella época fue Juan Vázquez de Mella y Fanjul, cuya pluma se dio a conocer en una serie de artículos donde criticaba a los integristas. A fines de 1896, participó en las conferencias de Loredán, convocadas por Carlos VII para actualizar el pensamiento tradicionalista, al socaire de los nuevos vientos social-católicos, reivindicando la restauración de los gremios y la extensión de las sociedades corporativas de producción y consumo ${ }^{63}$. A partir de las premisas social-católicas, Mella es esforzó en construir su propia variante de corporativismo, que llamó «sociedalismo jerárquico». Como en el caso de la construcción de Gil y Robles, el «sociedalismo" mellista es radicalmente antiestatista y hacía radicar la soberanía social en los cuerpos intermedios y en las ciases sociales, a las que corresponde la representación en las Cortes y en los ayuntamientos, a través de los cuales comparte la soberanía con el Rey. Esta concepción organicista llevaba a Mella a planteamientos regionalistas. España era una federación de regiones, con la que el Rey comparte la soberanía nacional. Y, por ello, la Monarquía debía ser federativa ${ }^{64}$.

\section{El DESASTRE DEL 98 Y LOS ORÍGENES DE LA DERECHA RADICAL: PERSISTEN- CIAS Y CAMBIOS.}

El «Desastre» español de 1898 no puede ser considerado como un hecho esencialmente castizo de la historia nacional. Como es sabido, existió igualmente un «98» francés, italiano y portugués, que puso de relieve la fragilidad del

62 GIL y Robles, Enrique: Tratado de Derecho Político según los principios del Derecho y la Filosofía cristianos, Madrid, 1960, tomo I, páginas 251 y ss.

${ }^{63}$ Ferrer, Melchor: Historia del Tradicionalismo Español, Sevilla, 1957, tomo XXVII, vol. II, páginas 102 y ss.

64 Vid. GAMBRA, Rafael: La Monarquía social y representativa en el pensamiento tradicional, Madrid, 1973. García y García De CASTRO, Rafael: Vázquez de Mella, Granada, 1940.

Hispania, LXI/1, núm. 207 (2001) 99-142 
sistema político y que tuvo como consecuencia el replanteamiento intelectual de la identidad nacional y de los valores sociales que hasta entonces habían configurado el imaginario colectivo. En estrecha coincidencia con ello, las sociedades europeas finiseculares experimentaron un período de profundos cambios psicológicos, de revuelta contra los principios del positivismo y la Ilustración ${ }^{65}$. Esta crisis tuvo como consecuencia el decaimiento de las ideologías tradicionales - liberalismo y conservadurismo-, y la emergencia de una gran variedad de reacciones, desde la extrema derecha a la extrema izquierda. En el campo de la derecha, la crisis trajo consigo la formulación ideológica de un conservadurismo radical, muy distinto del antiguo, forjado en las premisas de una perspectiva a veces cientificista, a veces vitalista, o irracionalista, en cuya óptica el engrandecimiento de la nación, entendida como un organismo colectivo, ocupaba un lugar prioritario, por encima del individuo y de los valores religiosos. Este nuevo conservadurismo radical tuvo sus adalides indiscutibles en Charles Maurras y L'Action Française, así como en Maurice Barrès, en cuya producción ideológica, distinta, aunque convergente, pueden percibirse las características de este nuevo «nacionalismo integral»: la exaltación de la nación y de las comunidades regionales, la crítica al proyecto de la modernidad desde instancias seculares, el odio al liberalismo y la democracia, el llamamiento al activismo, etc. ${ }^{66}$

Este nuevo conservadurismo tuvo una importante influencia en Italia, Portugal y Rumanía, e incluso en Hispanoamérica. En Alemania tendría un desarrollo distinto, basado sobre todo en el factor racial, que apenas tuvo repercusión en España, salvo en el nacionalismo vasco.

La derrota ante Estados Unidos sumió a las fuerzas de extrema derecha española en una sensación de perplejidad, que dio paso posteriormente a una actitud de interrogación. En un principio, para los carlistas supuso la reafirmación de sus profundas convicciones antiliberales. Gil y Robles vio en el «Desastre» la lógica consecuencia de la «revolución burguesa» llevada a cabo por los liberales, y que había instaurado la hegemonía social de una mesocracia «irreligiosa» e "hipócritamente pietista»: La solución no era otra que una dictadura a cargo de Carlos VII, que llevara a cabo una auténtica labor de deseuropeización. Ortí y Lara se limitó a decir que todo ello era fruto del «concepto de libre examen ${ }^{67}$. Menéndez Pelayo, por su parte, se sumió en un profundo silencio, aunque siguió exaltando a Balmes en sus conferencias y escritos ${ }^{68}$.

65 STUART Hughes, H.: Conciencia y sociedad. La reorientación del pensamiento social europeo, 18901930, Madrid, 1972. MosSE, George L.: La cultura europea del siglo XX, Barcelona, 1997.

${ }^{66}$ BoutANG, Pierre: Maurras, París, 1994. NGUYEN, Victor, Aux origines de L'Action Française. Intelligence et politique á laube du XX $X^{e}$ siècle, París, 1991. WEBER, Eugen: L'Action Française, París, 1985. STERNHELl, Zeev: Maurice Barrès et le nationalisme français, París, 1973.

67 CosTA, Joaquín: Oligarquía y caciquismo. Urgencia y modo de cambiarla, Madrid, 1975, tomo II, páginas 157 y ss y 209 y ss.

68 MENÉNDEZ Pelayo, Marcelino: «Dos palabras en el Centenario de Balmes», en Escritos de crítica filosófica, Madrid, 1948, páginas 155 y ss.

Hispania, LXI/1, núm. 207 (2001) 99-142 
Poco hubo de innovador en los manifiestos del general Camilo García Polavieja, quien, en un primer momento, recibió el apoyo de los integristas y otros sectores católicos. Polavieja no llegó a ser, desde luego, ni tampoco se lo planteó, el Boulanger español.

En realidad, las primeras manifestaciones del nacionalismo integral y/o de derecha radical es preciso buscarlas, en España, no en el conservadurismo tradicional, ni en el carlismo, ni en el integrismo, sino en los nacionalismos periféricos catalán y vasco; y posteriormente en los planteamientos críticos de lo que podemos llamar «espíritu del 98».

\subsection{Catalanismo y bizkaitarrismo}

Tanto el catalanismo como el bizkaitarrismo tuvieron, en sus orígenes, un rasgo en común: la afirmación de las diferencias culturales, lingüísticas y legales, frente a un Estado liberal débil, pero unitario, centralista y unificador en la medida de sus fuerzas. Sin embargo, estos movimientos no son equiparables, ya que se caracterizan por su heterogeneidad y su diversidad. Si bien el nacionalismo conservador español, e incluso el fascista, recibió la influencia del catalanismo, a través de la figura de Eugenio D'Ors, el bizkaitarrismo careció de transcendencia en el desarrollo ulterior de la extrema derecha española.

La iniciativa correspondió a los catalanistas, cuyo movimiento político surge, ante todo, como crítica al Estado liberal, crítica puntual y transcendente, no circunscrita a sus deficiencias, y que tenía sus antecedentes, no solo en la Renaixença, sino en la escuela tradicionalista de los apologistas catalanes y posteriormente en la obra del obispo Torras y Bagès. De hecho, las primeras recepciones de Maurras y Barrès en España estuvieron circunscritas al ámbito catalán y a los sectores catalanistas, que, durante el affaire Dreyfus, tuvieron una postura abiertamente pro-nacionalista y antidreyfusard ${ }^{69}$.

Su principal teórico, Enric Prat de la Riba, tuvo una formación cultural e ideológica muy semejante a la de Maurras: Joseph de Maistre, Auguste Comte, Fustel de Coulanges, Renan, Taine, etc. De acuerdo con su perspectiva organicistapositivista-tradicionalista, Prat, como Maurras, asimilaba sociedad a naturaleza; y, en consecuencia, concebía a la nación como una «comunidad natural, necesaria, anterior y superior a la voluntad de los hombres, que no pueden ni deshacerla ni mudarla». No deja de ser significativo que Prat denominara a su alternativa política «nacionalismo integral». Igualmente, Prat fue contrario al sistema parlamentario, que, para él, era sinónimo de desorden, fragmentación e incoherencia. Su alternativa era la representación corporativa «por gremios y profesiones» ${ }^{70}$.

69 Vid. COLl I AmARGós, Joaquim: El catalanisme conservador davant lafer Dreyfus, Barcelona, 1994, páginas 69 y ss.

70 PRAT DE LA RiBA, Enric: La nació i lestat. Escrits de joventut, Barcelona, 1987, páginas 103 y ss. La nacionalitat catalana, Barcelona, 1906, páginas 81 y ss .

Hispania, LXI/1, núm. 207 (2001) 99-142 
La movilización catalanista tenía su fin último en la consecución de un Estado propio; pero Prat no era separatista. Su alternativa era un Estado federal en el interior; y el imperialismo — «desde Lisboa hasta el Ródano»- en el exterior ${ }^{71}$.

Prat encontró en Eugenio D'Ors a un lúcido y dotado colaborador intelectual. Admirador de Maurras, Sorel y Moréas, D'Ors fue uno de los primeros intelectuales españoles que entró en contacto con L'Action Française, y de esa experiencia salió a la luz el movimiento «Noucentista», definido como un "nuevo intelectualismo», basado en los valores clásicos de jerarquía, continuidad y cultura frente al individualismo romántico ${ }^{72}$. Como en el caso de Prat, el «Noucentisme» culminaba en la idea de Imperio; y, sobre todo, en una crítica radical del liberalismo y de la democracia como representantes del «individualismo atomístico». Por contra, el Imperio representaba «la socialización, el Estatismo, el Estado educacional, la Ciudad, la idea de expansión de los pueblos, la Justicia Social, la lucha por la Ética y la Cultura»73. Ideas todas ellas que después serían recogidas por el fascismo español. A su marcha de Cataluña, D'Ors, que dejó allí un buen número de discípulos, llegó a convertirse, sin cambiar de perspectiva ideológica, en uno de los grandes teóricos de la derecha radical española.

Poco hay que decir, en cambio, del nacionalismo vasco, en cierta forma heredero de la tradición carlista, pero cuya impronta en el resto de España fue, y no sin razones, prácticamente nula. Su única novedad, pues su programa guardaba numerosos puntos de contacto con el integrismo nocedaliano, fue su formulación racial del hecho nacional. Su fundador, Sabino Arana, elaboró una especie de nacionalismo völkisch vasco, que resaltaba la pureza racial con respecto al mestizaje del resto de España, al que consideraba tan antinatural como nefasto ${ }^{74}$.

\subsection{El nuevo nacionalismo español y el espíritu del 98}

La crisis del 98 generó igualmente una reacción de tipo intelectual, que determinó una actitud y una mentalidad crítica ante la sociedad, que acabó diluyéndose, pero que, al mismo tiempo, marcó de forma indeleble la trayectoria política e intelectual de no pocos pensadores españoles. Lo que se ha venido en llamar «espíritu del 98» no es sino una reacción inconformista ante la situación

71 Vid. SOLÉ TURA, Jordi: Catalanismo y revolución burguesa, Madrid, 1974; páginas 219 y ss. Jardí Enric, Les doctrines juridiques, politiques $i$ socials d'Enric Prat de la Riba, Barcelona, 1974, páginas 143 y ss.

72 D'Ors Eugeni: Glosari, Barcelona, 1982, página 191

73 Ibidem, páginas 121 y ss. Vid. GonZález Cuevas, Pedro Carlos, «Charles Maurras en Cataluña», en Boletín de la Real Academia de la Historia, tomo CXCV, cuaderno II. Madrid, 1998; pp.309-362.Ver también el discutible libro de CACHO VIU, Vicente: Revisión de Eugenio D'bors. Madrid-Barcelona, 1997.

${ }^{74}$ Arana, Sabino: Obras Escogidas. Antología política, Bilbao, 1977, páginas 152 y ss. 
española y la búsqueda de una «tradición» sustentadora de un nuevo nacionalismo español 75 .

La élite intelectual noventayochista se encontraba, tanto a nivel ideológico como político, en las antípodas de todas las tradiciones de la extrema derecha española, católica y/o carlista. Pero sus ideas y planteamientos iban a influir de forma determinante, lo mismo que D'Ors, en el fascismo español. Y. además, algunos de sus representantes, como «Azorín» y Maeztu, militarían posteriormente en el conservadurismo y en el primorriverismo.

La nueva derecha antiliberal encontraría, por ejemplo, en la obra de Joaquín Costa - como ocurrió paralelamente en Italia con la figura de Alfredo Oriani; devenido precursor del fascismo- munición aprovechable: el organicismo social de raíz krausista, el historicismo tradicionalista, los proyectos de modernización hidraúlica; $y$, sobre todo, su ambigua denuncia del régimen de la Restauración -baluarte de caciques y oligarcas - , así como sus llamadas a la "revolución desde arriba» y al «cirujano de hierro» encargado de llevarla a cabo ${ }^{76}$.

Buena prueba de la ambivalencia de los intelectuales noventayochistas fue la trayectoria política de José Martínez Ruíz, «Azorín», quien, tras su escarceos federalistas y anarquizantes, pasó a militar, sin solución de continuidad, en el conservadurismo de Maura y La Cierva. "Azorín» fue, junto a D'Ors, uno de los introductores en España de los temas del nacionalismo integral maurrasiano, cuya influencia resulta patente en su obra Un discurso de La Cierva, en la que propugna una renovación del conservadurismo español a partir de Maurras y Barrès: estética clasicista, sociologismo comteano, agrarismo y antiliberalismo ${ }^{77}$.

Algo parecido podemos decir de Miguel de Unamuno, quien tampoco tuvo nunca una postura política coherente. Y cuya invocación a la «intrahistoria», a Castilla y sus críticas a los nacionalismos periféricos, así como su voluntarismo irracionalista, pasarían luego al acervo ideológico de nuestro fascismo ${ }^{78}$.

Menos metafísico se mostraba Ramiro de Maeztu en sus comienzos. A su juicio, el problema español estaba planteado en relación al desarrollo económico y a la consolidación de la unidad nacional amenazada por los nacionalismos periféricos. La solución se encontraba en una profunda reforma intelectual y moral, consistente en la secularización de las conciencias, la creación de nuevos mitos na-

7.5 Imman Fox, Edward: La crisis intelectual del 98, Madrid, 1976. Abellán José Luis, Sociología del 98, Barcelona, 1973. CACHO VIU, Vicente: Repensar el noventa y ocho, Madrid, 1997.

76 OrTí, Alfonso: Estudio introductorio a Oligarquía y caciquismo de Joaquín Costa, Madrid, 1975. PÉREZ DE la DeHeSA, Rafael: El pensamiento de Costa y su influencia en el 98, Madrid, 1966. MAURICE, Jacques y SERRANO, Carlos: Joaquin Costa: crisis de la Restauración y populismo, Madrid, 1977. VARELA, Javier: "La literatura del Desastre y el desastre de la literatura», en La Novela de España, Madrid, 1999.

77 «Azorín», Un discurso de La Cierva, Madrid, 1914, páginas 80 y ss. Con bandera de Francia, Madrid, 1950. p. 85 ss.

78 Cerezo Galán, Pedro: Las mascaras de lo trágico (Filosofía y tragedia en Miguel de Unamuno), Madrid, 1996.

Hispania, LXI/1, núm. 207 (2001) 99-142 
cionales, un nuevo sistema educativo basado en valores prácticos, no humanísticos, y en la colaboración del Ejército como baluarte de la unidad nacional ${ }^{79}$.

\section{CRISIS DE LA RESTAURACIÓN Y DICTADURA}

La quiebra del precario equilibrio canovista, a partir de 1898, pero, sobre todo, de 1913; la subsiguiente atomización de los partidos políticos dinásticos; el surgimiento de nuevos grupos sociales, al socaire del crecimiento económico de principios de siglo; la crisis provocada por el estallido de la Gran Guerra y por la "corporativización" de la sociedad, que ponían en cuestión los supuestos del sistema liberal; el progresivo aumento de la movilización social y política, así como el triunfo de la revolución bolchevique en Rusia, iban a tener importantes consecuencias en el desarrollo de la extrema derecha española, que se vio obligada a modernizar su proyecto político; y en la mayor diversificación de sus tradiciones.

En ese sentido, uno de los hitos fundamentales en la historia de los sectores antiliberales españoles fue la aparición de la Asociación Católica Nacional de Propagandistas en 1909. Su ideología y proyecto político eran una actualización de la tradición católica en su versión balmesiana, junto a las nuevas perspectivas abiertas por el catolicismo social ${ }^{80}$. Su órgano de difusión fue El Debate y su principal directivo, Ángel Herrera Oria. Salvo en lo relativo a la difusión de los planteamientos social-católicos y la organización de élites de orientación, Herrera y sus propagandistas fueron incapaces de modernizar el contenido del discurso católico; carecieron de la audacia de la novedad. Siguiendo a Menéndez Pelayo, Herrera identificaba a la nación española con los valores católicos y monárquicos. Al mismo tiempo que se mostraba contrario a la democracia liberal, que «no se había creado para España». En ese sentido, su alternativa era «una forma de democracia orgánica que empiece por vivificar con savia del pueblo las primeras instituciones de la vida pública y de las instituciones económicas» ${ }^{81}$.

De la misma forma, el movimiento católico-social español se mostró, salvo en casos muy aislados, afín a la perspectiva tradicionalista y contrarrevolucionaria. Sus principales teorizantes y organizadores, como los Padres Gafo o Gerard, no digamos el célebre Marqués de Comillas, fueron profundamente antiliberales y afines a posturas paternalistas y antisindicales ${ }^{82}$.

\footnotetext{
79 GonZález Cuevas, Pedro Carlos: «Nacionalismo y modernización en la obra del primer Maeztu», en Hispania, nº 184, 1993, páginas 557 y ss.

80 Vid. ORdovés, José Miguel: Historia de la Asociación Católica Nacional de Propagandistas, Pamplona, 1993.

81 Herrera ORIA, Ángel: Obras selectas, Madrid, 1965, páginas 5-8, 75 y ss.

82 BENAvides, Domingo: El fracaso social del catolicismo español. Arboleya Martínez, Barcelona, 1974. CARRASCo CAIVO, Salvador: Los sindicatos de dominicos Gerard y Gafo. De la innovación neotomista a la Dictadura, Barcelona, 1982. CASTILlO, Juan José: El sindicalismo amarillo en España. Aportación al estudio del catolicismo social español, Madrid, 1977.
}

Hispania, LXI/1, núm. 207 (2001) 99-142 
Igualmente importante fue la aparición del maurismo como grupo político diferenciado, tras la escisión conservadora de 1913. Resulta significativo que su máximo teórico, Antonio Goicoechea, definiera al nuevo movimiento derechista como la antítesis del canovismo. No el individualismo posesivo, sino el intervencionismo estatal; no el liberalismo doctrinario, sino la «democracia conservadora»; y, sobre todo, no el resignado pesimismo canovista, sino la fe inquebrantable en «el espíritu creador y en las inagotables energías de la raza». De esta manera hacía su aparición el primer grupo político español en el que podemos ver ciertos rasgos de derecha radical, si bien el elemento católicotradicional tuvo un considerable paso en el conjunto de su ideología. Formado en las corrientes social-católicas, Antonio Goicoechea fue un crítico radical del régimen de la Restauración, al que opuso la «democracia conservadora y orgánica», un sistema político intervencionista, corporativo y nacionalista, que no sólo debía respetar la genuina espiritualidad española, sino restaurarla. Como Balmes y Menéndez Pelayo, Goicoechea identificaba la tradición española con la Monarquía y el catolicismo. Pero, al lado de todo esto, el líder maurista fue uno de los primeros políticos españoles que recogió algunas de las fórmulas maurrasianas en sus discursos, como la doctrina del «empirismo organizador», la crítica al romanticismo y la identificación de la Monarquía con el «nacionalismo integral» 83 . Igualmente, el tradicionalismo carlista teorizado por Vázquez de Mella tuvo su continuador en Víctor Pradera. Más sistemático que Mella, Pradera acentuó ideológicamente la evolución del tradicionalismo carlista desde el regionalismo a la definición de un movimiento en el que el dinastismo fue cediendo paso a las idea corporativas, organicistas y a la apología directa del golpe de Estado militar, así como a la exaltación de la unidad nacional frente a los nacionalismos periféricos. Desde los comienzos de su carrera política, caracterizó a Pradera una profunda enemistad con respecto a los nacionalismos, cuyas reivindicaciones carecían, a su juicio, de todo fundamento histórico y de legitimidad doctrinal. Ni la diferenciación cultural, ni la raza podían servir para fundamentar la independencia de Cataluña o el País Vasco. Los fueros no podían ser interpretados como códigos de soberanía, según había hecho Sabino Arana; eran «el gran título de amor de Vasconia a España». Y, en ese sentido, la alternativa al centralismo liberal no era otra que el foralismo carlista, consistente en la restauración de las autarquías regionales. siguiendo el ejemplo histórico de la España de los Reyes Católicos, mediante la instauración de la «Monarquía federativa» ${ }^{84}$. Pradera acompañó a Vázquez de Mella en su disidencia frente al nuevo rey carlista, Don Jaime, tras el final de la Gran Guerra, en 1919.

83 GoIcoecheA, Antonio: Hacia la democracia conservadora, Madrid, 1914. La crisis del constitucionalismo moderno, Madrid, 1925. Horas de ocio (Discursos y artículos literarios), Madrid, 1925. El problema de las limitaciones de soberanía en el derecbo público contemporáneo, Madrid, 1923.

84 PRADERA, Víctor: Regionalismo y nacionalismo, Madrid, 1917. El misterio de los fueros vascos, Madrid, 1918. Fernando El Católico y los falsarios de la Historia, Madrid, 1922. 
El emergente conservadurismo radical español contó, aparte de las ya mencionadas contribuciones de "Azorín" y D'Ors con la de José María Salaverría, portaestandarte de un nuevo nacionalismo español, muy distinto del católico propugnado por los mauristas y por los propagandistas de Herrera. Influido desde muy temprano por Schopenhauer y Nietzsche, y posteriormente por Maurras, Salaverría atacó a la llamada «Generación del 98», a la que acusó de individualismo romántico, antipatriotismo y antimilitarismo. Frente al negativismo noventayochista, el escritor vasco propugnaba imbuir a las nuevas generaciones de un espíritu patriótico, heroico y optimista. En ese sentido, el enemigo a batir no era solo el noventayochismo, sino, sobre todo, los nacionalismos periféricos, "grietas de donde se escapa la mejor fuerza de España»; y el movimiento obrero revolucionario, representante del «subpueblo» $^{85}$.

A medio camino entre la teología política y la derecha radical, se encontraba en aquellos momentos Ramiro de Maeztu, quien, tras su antigua militancia noventayochista y liberal-socialista, había evolucionado, conmovido por el desarrollo de la Gran Guerra, hacia el catolicismo; de lo que fue testimonio su obra La crisis del bumanismo, donde sometía, bajo la influencia de Thomas E. Hulme y del "guildismo» británico, a una dura crítica los fundamentos del proyecto de la modernidad. Sólo mediante el retorno a los cánones del «clasicismo cristiano», superador del relativismo humanista y romántico, causantes de la hecatombe mundial, podían las sociedades europeas recuperar la estabilidad y la confianza en sí mismas. El «clasicismo cristiano» llevaba a una concepción comunitaria y corporativista de la sociedad basada en el principio de «función», que conducía a la restauración de los gremios como correctivo frente al atomismo liberal y al colectivismo socialista, productos ambos de la modernidad ${ }^{86}$.

Como Renan a decir de Mussolini, José Ortega y Gasset tuvo igualmente «iluminaciones prefascistas» ${ }^{87}$. Filosóficamente, Ortega lanzó un ataque frontal contra el racionalismo y el positivismo apoyado en el historicismo y en el vitalismo; y, en consecuencia, su perspectiva filosófica supuso una revalorización del mundo de las pasiones, de las fuerzas vitales que mueven la historia. Políticamente, fue un liberal-conservador, en cuyos escritos se expresaron la mayoría de los motivos del pensamiento elitista y conservador: el realismo histórico, el sentimiento del valor de la continuidad, una teoría de la nación como empresa integradora; $y$, finalmente, un sentimiento fuertemente aristocrático de la sociedad y de la vida, en el que los pocos están llamados a dirigir a los muchos ${ }^{88}$. Pero la aportación orteguiana a la forja de una derecha radical y/o revolucionaria no se redujo a sus teorías filosóficas o sociales; influyó igualmente a través

85 SALAVerRía, José María: La afirmación española, Barcelona, 1917. El muchacho español, Madrid, 1917. En la vorágine. El hervor multitudinario, Madrid, 1919.

${ }^{86}$ MAEzTU, Ramiro de: La crisis del humanismo, Barcelona, 1919, páginas 55 y ss.

87 Mussolini, Benito: El fascismo, Barcelona, 1976, página 28.

88 Vid. FernÁNDEZ DE LA MORA, Gonzalo: Ortega y el 98. Madrid, 1979. EloRZA, Antonio, La razón y la sombra. Una lectura política de Ortega y Gasset, Barcelona, 1987.

Hispania, LXI/1, núm. 207 (2001) 99-142 
de su Revista de Occidente, en la que colaboraron los futuros teóricos del fascismo español, Ramiro Ledesma Ramos y Ernesto Gímenez Caballero; y en cuyas páginas y en cuya editorial se publicaron libros y artículos de intelectuales afines a la llamada «revolución conservadora» alemana, como Werner Sombart, Carl Schmitt, Hermann Keyserling, Othmar Spann y Oswald Spengler ${ }^{89}$.

Tras su famosa expulsión de los organismos culturales de la Mancomunidad catalana, Eugenio D'Ors marchó a Madrid, donde fue recibido cordialmente por el conjunto de la elite intelectual. El filósofo catalán fue profundizando en su teoría política, mostrándose partidario de un régimen corporativo ${ }^{90}$. Y su influencia se extendió al País Vasco, donde fueron tributarios de su pensamiento jóvenes escritores como Ramón de Basterra y los futuros falangistas Pedro Mourlane Michelena y Rafael Sánchez Mazas, grupo intelectual que se autodenominó «Escuela Romana del Pirineo». Su pensador más influyente fue Basterra, representante de una nueva especie de despotismo ilustrado - el «carlotercismo»- opuesto al sistema liberal. Como poeta creó el personaje de Virulo, héroe obsesionado por el ímpetu de la acción y fascinado por la creación de un nuevo Imperio español, la «Sobreespaña»"1.

Admirador de Maurras, Rafael Sánchez Mazas se encargó, como corresponsal de $A B C$ en Italia, de describir elogiosamente la subida al poder de Mussolini y sus fascistas ${ }^{92}$.

Igualmente, tuvo alguna importancia para la recepción de las fórmulas maurrasianas en España, la estancia en nuestro país de Antonio Sardinha, líder intelectual del Integralismo Lusitano, a raíz de su exilio tras la fracasada rebelión monárquica de Monsanto. Sardinha colaboró en El Debate, El Pensamiento Español y la revista Raza Española. Por su parte, el Conde de Santibáñez del Río, amigo de Sardinha y futuro fundador de Acción Española, contribuyó a divulgar la ideología integralista con su libro Portugal y el hispanismo $0^{93}$.

De todas formas, no debemos exagerar la influencia de estas ideas en el conjunto de las derechas españolas, ya que, como afirmaba el maurrasiano Álvaro Alcalá Galiano en vísperas del golpe militar primorriverista, al conservador español le bastaba «saber, sin leerlos, que las derechas católicas cuentan con campeones literarios como Balmes y Menéndez Pelayo, y que las gentes bienpensantes pueden leer las novelas de Alarcón y Pereda sin caer en el pecado» ${ }^{94}$.

89 Vid. LóPEZ-CAMPILlo, Evelyne: La Revista de Occidente y la formación de minorías, Madrid, 1972, páginas 82 y ss.

90 D'Ors, Eugenio: «Aprendizaje y heroísmo», en Diálogos, Madrid, 1981, páginas 62 y ss.

91 Vid. DíAz-PLAJA, Guillermo: La poesía y el pensamiento de Ramón de Basterra, Barcelona, 1941. AREAN, Carlos, Ramón de Basterra, Madrid, 1950.

92 «La victoria fascista y la marcha sobre Roma» en $A B C$, 15-XI-1922, «Retraro de Mussolini», en $A B C, 15-\mathrm{II}-1923$. «La crisis del fascismo», en $A B C, 16$ y 20-VI-1923, «El Imperio o la muerte", $A B C, 30$-VI-1923.

93 Vid. GoNZÁLEZ CUEvas, Pedro Carlos: «El Integralismo Lusitano: su recepción en España», en Proserpina, $\mathrm{n}^{\circ} 11,1994$, páginas 79 y ss.

94 «Intelectuales reaccionarios», $A B C, 25-1-1923$. 
En ese sentido, la Dictadura primorriverista, a la que el conjunto de la derecha y de la extrema derecha española dio su apoyo, y en la que colaboraron Maeztu, D'Ors, Salaverría y Pradera, no supuso apenas innovaciones doctrinales o ideológicas. Pese a que cuando se produjo existía ya el fascismo en Italia, la Dictadura no tuvo nada de fascista; es más: su advenimiento supuso, de hecho, un dique a la emergencia de un movimiento fascista español. En la medida que estuvo asistida por algún pensamiento, éste fue el conservador autoritario tradicional, con ciertos aditamentos costistas y tecnocráticos. Su innovación más reseñable fue la edificación del sistema corporativo, según las premisas social-católicas, cuyo máximo teorizante fue Eduardo Aunós, ministro de Trabajo de Primo de Rivera, antiguo militante de la Lliga, admirador por entonces de Maurras, La Tour du Pin y Ketteler ${ }^{95}$.

El general Primo de Rivera no intentó en ningún momento convertirse en un caudillo carismático; y su dictadura giró, a lo largo de toda su existencia, entre la variante comisoria y soberana. Sólo en sus últimos años se planteó la instauración de un Estado autoritario permanente, que rompiera con la tradición liberal-conservadora. En ese sentido, es preciso destacar las obras de dos de los ideólogos de la Unión Patriótica, el partido de Primo de Rivera, José María Pemán, El hecho y la idea de la Unión Patriótica; y de José Pemartín, Los valores históricos en la Dictadura española, insertos ambos en la tradición teológico-política. No en vano el lema de la Unión Patriótica recordaba al de los carlistas: «Patria, Religión y Monarquía». Tanto Pemán como su primo Pemartín planteaban la evolución de la Dictadura hacia la Monarquía tradicional y representativa ${ }^{96}$. Este proyecto intentó plasmarse, al menos en parte, en la nonnata Constitución de 1929, cuyo articulado no llegó siquiera a discutirse por la caída de la Dictadura a comienzos de $1930^{97}$.

\section{FRENTE A LA REPÚbliCA: EL TRIUNFO DE LA TEOLOGÍA POLÍTICA}

El advenimiento de la II República en abril de 1931 supuso la puesta en marcha de un serio intento de modernización de la sociedad y del Estado; lo cual suscitó la oposición y resistencia de los sectores sociales y políticos más representativos del anterior régimen monárquico y del conjunto de las mentalidades conservadoras. Así ocurrió en las relaciones entre la Iglesia y el Estado, ya que los proyectos secularizadores republicanos suponían una serie de contenidos radicalmente anticlericales. Igualmente dura fue la resistencia de los grandes propietarios agrarios a los proyectos de reforma. Esta resistencia solo

\footnotetext{
95 Aunós, Eduardo: El discurso de la vida. Autobiografía, Madrid, 1951, páginas 75, 125 y ss.

96 Gómez Navarro, José Luis: El régimen de Primo de Rivera, Madrid, 1991. Álvarez ChilliDA, Gonzalo: José María Pemán. Pensamiento y trayectoria de un monárquico (1897-1941), Cádiz, 1996.

97 García CANAles, Mariano: El problema constitucional en la Dictadura de Primo de Rivera, Madrid, 1980.
}

Hispania, LXI/1, núm. 207 (2001) 99-142 
fue comparable a la que se opuso a los estatutos de autonomía. La formulación ideológica de la oposición conservadora y tradicionalista a la II República tuvo su máxima expresión en la revista y sociedad de pensamiento monárquica $A c$ ción Española, fundada a finales de 1931 por el Conde de Santibáñez del Río, Ramiro de Maeztu y el antiguo integrista Eugenio Vegas Latapié. Acción Española tuvo como objetivo lograr la síntesis de todas las tradiciones contrarrevolucionarias españolas; y en ella colaboraron antiguos mauristas, como Goicoechea y Calvo Sotelo; carlistas, como Víctor Pradera y el conde de Rodezno; primorriveristas, como Pemán, Pemartín y Aunós; menendezpelayistas, como Pedro Sáinz Rodríguez; integristas, propagandistas católicos, etc. Su título, traducción directa del órgano doctrinal de Charles Maurras, no debe llevarnos a engaño, pues la tradición dominante en la revista fue, pese a que en ella colaboraron algunos maurrasianos, la teológico-política. El secularismo positivista de Maurras fue muy criticado en sus páginas. El proyecto político de Acción Española fue una actualización del tradicionalismo católico, a través de la interpretación menendez-pelayana de la historia nacional, la teoría monárquicotradicional del Estado y el coporativismo social-católico ${ }^{98}$.

Con todo, la novedad política más trascendental del período republicano fue la aparición de Acción Popular y luego la Confederación Española de Derechas Autónomas como movimiento derechista de masas. La novedad del cedismo, obra de los propagandistas católicos de Herrera, no fue ideológica, sino organizativa. Como en el caso de los monárquicos de Acción Española, la ideología cedista fue expresión de las exigencias y de los intereses de una sociedad básicamente preindustrial. Por lo demás, si el nuevo partido tuvo un éxito electoral que fue más allá de las optimistas previsiones de sus promotores, ello dependió del hecho de que la sociedad española era todavía en grandísima parte, no sólo en los intereses y necesidades, sino en los valores transmitidos y aceptados, una sociedad agraria con profundas diacronías en su seno. La ideología de la CEDA fue una síntesis el tradicionalismo cultural, socialcatolicismo y conservadurismo autoritario. Su líder, José María Gil Robles, hijo de Enrique Gil y Robles, fue un claro defensor del tradicionalismo corporativo, más influido por la perspectiva de su progenitor ${ }^{99}$. Su órgano doctrinal, la Revista de Estudios Hispánicos, dirigida por el marqués de Lozoya, y colocada bajo el patrocinio intelectual de Menéndez Pelayo, Antonio Sardinha, Milá y Fontanals y Luis de Camoes, fue, salvo en el tema de las formas de gobierno, un plagio consciente de Acción Española, y en sus páginas se propugnó un Estado autoritario, corporativo y confesional, cuyo modelo más próximo fue el Portugal salazarista ${ }^{100}$.

98 GonZÁlez Cuevas, Pedro Carlos: Acción Española. Teología política y nacionalismo autoritario en España (1913-1936). Madrid, 1998. Del mismo autor, Historia de los derechos españoles. De la Ilustración a nuestros días. Madrid, 2000.

99 GIL Robles José María: El Derecho y el Estado y el Estado de Derecho, Salamanca, 1922. Discursos parlamentarios, Madrid, 1969.

100 GONZÁlez CUEVAS: op. cit., páginas 277 ss. 
Igualmente, existió en el tradicionalismo carlista una cierta preocupación intelectual, que se concretó en la revista Tradición, fundada en Santander en 1934 y que duró hasta el año siguiente. En sus páginas siguieron defendiéndose las fórmulas del sociedalismo mellista ${ }^{101}$. No obstante, el hito doctrinal del carlismo fue la publicación por parte de Víctor Pradera de su obra El Estado nuevo, vademecum del pensamiento tradicionalista, cuyos capítulos habían aparecido anteriormente en las páginas de Acción Española. La obra supuso la reafirmación de los viejos tópicos carlistas: iusnaturalismo, organicismo, foralismo y Monarquía tradicional federativa ${ }^{102}$.

Otra de las novedades del período republicano fue la consolidación definitiva del fascismo español como alternativa política, si bien en una forma muy marginal, al menos hasta el estallido de la guerra civil. Históricamente, el movimiento fascista fue la expresión social de una clases medias «emergentes», deseosas de una mayor participación en el poder social y político; y su ideología fue una peculiar mezcla de elementos nacionalistas, populistas y socialistas. En ese sentido, tanto el movimiento como luego el régimen fascista se distinguió de los sistemas políticos conservadores en cuanto promocionó la movilización de las masas y por su pretensión de mostrar una nueva faz de civilidad, su idea de crear un "hombre nuevo" y una nueva sociedad ${ }^{103}$. El máximo teorizante del fascismo español fue, sin duda, Ramiro Ledesma Ramos, joven filósofo formado en la escuela de Ortega y Gasset y atento lector de Unamuno, Heidegger, Nietzsche, Gentile, Maurras y Sorel. Formado al margen de la Iglesia católica, en sus escritos políticos y filosóficos subyace un profundo anticatolicismo. En el fondo, Ledesma llegó a la conclusión de que el fascismo solo podría triunfar en España una vez que el catolicismo y la Iglesia, instrumentos de «debilidad y resquebrajamiento», hubieran perdido su hegemonía social e ideológica. Tanto el racionalismo como el catolicismo representaban pseudovalores que obstaculizaban la necesaria primacía de lo vital y dionisíaco. En el caso concreto del catolicismo, éste había mermado no sólo el desarrollo científico y filosófico español, sino la cristalización de un auténtico nacionalismo, que «alcanzase a todos los españoles por el solo hecho de serlo, no por otra cosa que además sean». El problema español radicaba en la consolidación de la unidad nacional y el logro de la independencia económica, para lo que se necesitaba un nuevo Estado, realmente nacional, que reformase a la sociedad mediante el intervencionismo económico e integrara a las masas a través de sus instituciones ${ }^{104}$.

Fundador del semanario La Conquista del Estado y luego del partido Juntas de Ofensiva Nacional-Sindicalista, Ledesma fue el auténtico creador de los sím-

\footnotetext{
101 Ibidem, páginas 244 ss.

102 PRADERA Víctor: El Estado nuevo, Madrid, 1935.

103 DE Felice, Renzo: El fascismo. Sus interpretaciones, Buenos Aires, 1976. STERnHELL, Zeev: El nacimiento de la ideología fascista, Madrid, 1994.

${ }^{104}$ LEDESMA RAmOS, Ramiro: El sello de la muerte, Madrid, 1924. El Quijote y nuestro tiempo, Madrid, 1971. Discurso a las juventudes de España, Madrid, 1935.
}

Hispania, LXI/1, núm. 207 (2001) 99-142 
bolos del fascismo español: la bandera roja y negra; los lemas «Una, Grande y Libre», «Patria, Pan y Justicia», «Revolución Nacional», etc. En realidad, todo el mordiente doctrinal del falangismo procede de Ledesma, en particular su antiliberalismo, la apelación a las masas trabajadoras y la economía dirigista. La superación falangista del dilema entre izquierdas y derechas fue también herencia del jonsismo.

A su lado, José Antonio Primo de Rivera y Ernesto Gímenez Caballero ocupan el lugar de epígonos. El primero careció de la coherencia de Ledesma. Sus vacilaciones al estudiar los problemas sociales y políticos son muestras aisladas, pero significativas de unos planteamientos en los que siempre dominó la inconcreción. El fracaso político de su padre le empujó a estudiar con celo el pensamiento y el estilo de Unamuno, Ortega y, D'Ors, desde un punto de vista fascista. Su máxima aportación fue, en ese sentido, el concepto de nación. Siguiendo a D'Ors y a Ortega, Primo de Rivera rechazaba la visión romántica de nación, característica del catalanismo y el bizkaitarrismo, basada en sus rasgos físicos; por el contrario, la nación ha de ser considerada, ante todo, como un proyecto, un mandato, una norma que cumplir. Para ello, está el concepto de «unidad de destino», que se concreta en la expansión exterior, en la voluntad de Imperio y de liberación de los enemigos tanto exteriores como interiores ${ }^{105}$.

Autodenominado «nieto del 98», Ernesto Gimenez Caballero fue, ante todo, un literato, en cuya obra se impone la invención fantasiosa a la dimensión práctica, la superficialidad sobre la radicalidad, la improvisación sobre el sistematismo y la ocurrencia sobre la teoría. Para el vanguardista madrileño, el fascismo era la fórmula política más afín al «genio» sincrético característico de la nación española, mezcla del colectivista genio oriental y del individualista genio occidental. En ese sentido, el fascismo era la «Nueva Catolicidad»; no porque fuese un catolicismo en tanto teología política, sino como doctrina moderna «universal» 106 .

No sabemos lo que, por sí mismo, hubiera sido el fascismo español. Sabemos lo poco que fue a lo largo del período republicano. El conjunto de las fuerzas políticas de la derecha y la extrema derecha, a pesar de sus coyunturales alabanzas como eficaz destructor de la democracia liberal y del movimiento obrero revolucionario, rechazó los contenidos del proyecto político fascista, ajeno a las características de su cultura política. Para los carlistas, el fascismo era un "sarampión», una moda repleta de peligros, carente de porvenir en una nación como España ${ }^{107}$. Expresión propia de la modernidad, mecanicista y ra-

105 Primo De Rivera, José Antonio: «Ensayo sobre el nacionalismo», en Obras Completas, Madrid, 1976, tomo I, páginas 347 y ss.

106 Giménez Caballero, Ernesto: Genio de España, Madrid, 1932. La Nueva Catolicidad, Madrid, 1933. Ver también Selva Roca De Togores, Enrique, Giménez Caballero. Entre la Vanguardia y el fascismo. Valencia, 1999.

107 «Una moda politica», en Tradición, n² 29, 1-III-1934, páginas 97-98. 
cionalista, dirá José Pemartín, en Acción Española ${ }^{108}$. Fruto del materialismo «que brota de las siembras de rebelión antirreligiosa efectuadas en el siglo XVI por la mano del Renacimiento que somete el espíritu al dominio de la sensualidad», sostuvo Oscar Pérez Solís, en la Revista de Estudios Hispánicos ${ }^{109}$.

Puede haber pocas dudas de que la tradición triunfante fue, una vez más, la teológico-política. A ella la correspondió, en definitiva, legitimar el alzamiento de julio de 1936. No en vano, el derecho a la rebeldía fue teorizado en las páginas de Acción Española por eclesiásticos como Aniceto de Castro Albarrán y Pablo León Murciego, así como por teólogos seglares como Marcial Solana ${ }^{110}$. Planeado, siguiendo la tradición militar, como un estricto pronunciamiento, el alzamiento fracasó, desencadenando una larga y cruenta guerra civil. La mera defensa del orden social, suficiente en principio para legitimar un golpe militar, no lo era propagandísticamente para una guerra civil. Una vez más, la religión sirvió para dotar de sentido transcendente al conflicto, presentándolo como una auténtica «Cruzada», cuyo máximo teorizante fue el cardenal Isidro Gomá, colaborador de Acción Española durante la República ${ }^{111}$. El anticlericalismo republicano-socialista-anarquista-comunista y los muchos asesinatos de sacerdotes y monjas en su retaguardia a lo largo de la contienda sirvieron para confirmar tal imagen de la guerra, que la jerarquía eclesiástica se apresuró a refrendar.

\section{LA ERA DE FRANCO: DE LA EDAD DE ORO A LA CRISIS}

El sistema político nacido de la guerra civil fue, en realidad, el recipiente en el que llegaron a confluir todas las tradiciones de derecha y de extrema derecha opuestas a la significación de la II República. No sin cierta simplificación, puede decirse que el régimen de Franco consiguió aglutinar tanto a los contrarrevolucionarios a la antigua como a los sectores específicamente fascistas, cuyo número aumentó ostensiblemente durante la guerra civil, de modo que, durante algún tiempo, mas o menos hasta el final del conflicto mundial, pudo presentar la doble faz antitética de un movimiento que deseaba un orden nuevo, siguiendo los ejemplos totalitarios de Italia y Alemania; y la de un movimiento restaurador que quería pura y simplemente el retorno del orden tradicional.

Finalmente, el régimen acaudillado por Franco no llegó a ser lo que hubiera querido un fascista español; fue el régimen querido y soñado por el conjunto de las derechas tradicionales. Supuso la edad dorada de las derechas españolas: la

\footnotetext{
108 «Cultura en exceso», en Acción Española, n 55, 16-VI-1934, páginas 92-93.

109 «La situación social del mundo», en Revista de Estudios Hispánicos, n 4, abril 1935, páginas 421 y ss.

110 Castro Albarrán, Aniceto de: El derecho a la rebeldía, Madrid, 1934. «El derecho de resistencia», en Acción Española, no 43, 16-VII-1933, páginas 241 y ss.

111 GOMÁ, Isidro: Pastorales de la guerra de España, Madrid, 1955. 
religión, la Patria, la familia, el orden, la unidad nacional, la propiedad fueron, a un tiempo, los valores más protegidos y las columnas del régimen.

El sistema político fue, a lo largo de toda su existencia, mucho más personal que institucionalizado. Durante la contienda, el general Franco, siempre pragmático y poco concernido por lo que sin duda le parecieron escolásticas sutilezas político-intelectuales, tuvo como primer objetivo ganar la guerra, y para ello necesitaba un frente y una retaguardia perfectamente unidas. $Y$ así en abril de 1937 dictó el Decreto de Unificación de Falange y el Tradicionalismo, al que se adhirieron, sin demasiada dificultad, el resto de las fuerzas políticas confluyentes en el alzamiento de julio. Desde entonces, el régimen se convirtió en lo que básicamente siempre fue, un caudillaje personal, apoyado por el conjunto de las clases conservadoras del país. Franco acertó a colocarse por encima de las distintas fuerzas políticas y, gracias a su imagen de «Salvador de España», le fue atribuida una personalidad carismática, de la que se aprovechó para afirmar su poder de "Caudillo», que resultó decisivo.

Lo cual no significa que el sector falangista careciese de importancia en la configuración del nuevo Estado. Mientras duró la guerra mundial, los falangistas consiguieron que se creasen organismos importantes, como el Instituto de Estudio Políticos, el partido único - FET de las JONS - , el Frente de Juventudes y el Sindicato Español Universitario; y que se promulgasen leyes fascistas como el Fuero del Trabajo, muy aguadamente los puntos de Falange y se fundaran revistas como Jerarquía y luego Escorial. En ese sentido, el sector falangista contó con un selecto grupo de intelectuales, seguidores de Ortega y D'Ors, que, en un primer momento, contribuyeron eficazmente a legitimar el orden político nacido de la guerra civil. Entre ellos es preciso destacar a Luis Legaz Lacambra, quizá el principal teorizante del partido único español. Siguiendo en lo fundamental a Carl Schmitt, Legaz partía de la crisis del Estado liberal, «un Estado desintegrado en falsos antagonismos». Su contraste, el sistema de partido único, no estaba basado en la polémica, sino en el criterio opuestos, que, «por ser único excluye la relación de alteridad, no puede dialogar, entrar en discusión con otro». En ese sentido, la relación capital era la existente entre Estado y partido. Para Legaz, el partido no es un órgano del Estado, ni un ente autárquico, ni una corporación de derecho público; es «una ecclesia, que guarda con el Estado una relación ontológica y jerárquica a lo que en tesis católica mantiene el Estado católico con la Iglesia católica». De lo que se deducía una serie de consecuencias políticas. El credo y el dogma deben ser respetados por el Estado, que comprende a los hombres que constituyen el movimiento político, y que adquieren el compromiso de protegerlo jurídicamente, persiguiendo la «herejía» política y exigiendo a los altos cargos lealtad a los ideales ${ }^{112}$.

112 LEGAZ LACAMBRA, Luis: Introducción a la teoría del Estado nacional-sindicalista, Barcelona, 1941 , páginas 125 y ss. 
No menos importante fue la labor ideológica de Francisco Javier Conde, el discípulo español más importante de Carl Schmitt. Su aportación más reseñable a la legitimación del régimen fue su teoría del caudillaje, a la que tampoco era ajena la influencia de Max Weber y la del propio Schmitt, sobre todo la crítica de éste último al intento kelseniano de sustituir el mando y el poder de los hombre concretos, capaces de «acaudillar carismáticamente», por el imperio de las normas abstractas ${ }^{113}$.

A su lado, hay que destacar la labor de jóvenes intelectuales como Pedro Laín Entralgo, obsesionado por perfilar una ética nacional falangista acorde con los valores religiosos del catolicismo ${ }^{114}$, o Antonio Tovar y José Antonio Maravall, cuyos estudios de la época estaban encaminados a exaltar el Imperio y el pensamiento español del Siglo de Oro ${ }^{115}$. No obstante, tanto Laín como Tovar y Maravall se esforzaron en preservar el legado noventayochista y orteguiano, que formaba parte de la genealogía del pensamiento falangista, de las críticas del catolicismo integrista.

La arrolladora expansión de la Alemania hitleriana pudo haber hecho creíble por algún tiempo el despliegue de los planteamientos totalitarios en España. Pero el sueño de un totalitarismo pleno se disolvió pronto en retórica inútil, dada la realidad de una España en ruinas, dividida y tutelada por un clero sumamente conservador; y que, además, veía deshacerse en humo las empresas políticas de Alemania e Italia. No obstante, Falange seguiría ejerciendo influencia en el régimen nacido de la guerra civil. Por de pronto, éste tomó y utilizó, a lo largo de toda su existencia, sus símbolos políticos; y aprovechó la retórica y el contenido de algunas de sus propuestas para garantizarse la adhesión de ciertos sectores de las clases medias y populares. Fue el representante, en fin, del populismo franquista y su rol fue operativo durante mucho tiempo. En aquellos momentos, una Monarquía tradicional como la propugnada por Acción Española hubiera sido una fórmula política incapaz de disimular siquiera su carácter de "Antiguo Régimen», un poder autoritario que no disponía de más argumento a su favor que la legitimidad dinástica y, en consecuencia, se encontraba desprovisto de sentido carismático secularizado, y que tenía que renunciar, por principio, a palabras, aunque fuesen únicamente retóricas, como «revolución», de toda apelación popular. De haber seguido esa vía, es previsible que el régimen hubiera durado mucho menos.

No obstante, el pensamiento falangista, tras la derrota del Eje, entró en un serio e irreversible declive, del cual fue incapaz de salir, limitándose a repetir las viejas fórmulas, sin posibilidad de renovación. Dentro de esa corriente, tan sólo son reseñables los intentos del filósofo Adolfo Muñoz Alonso, cuya peculiar

113 CONDE, Francisco Javier: «Espejo de caudillaje», en Escritos y fragmentos políticos, Madrid, 1974, tomo I, páginas 30 y ss.

114 LaÍn ENTRALGo, Pedro: Valores morales del nacional-sindicalismo, Madrid, 1941.

115 Tovar, Antonio: El Imperio de España, Madrid, 1941. MARAVAll, José Antonio: Teoría del Estado en España en el siglo XVII. Madrid, 1943

Hispania, LXI/1, núm. 207 (2001) 99-142 
dialéctica, plagadas de inconcreciones y paradojas, fue un reflejo más de la profundidad de la crisis. Fundamentalmente, Muñoz Alonso intentó enfatizar el carácter católico del pensamiento de José Antonio Primo de Rivera -ignorando por completo a Ledesma Ramos-, en la línea de las corrientes "personalistas» que arrancan de Mounier ${ }^{116}$. Otros intentos, como los de José Luis de Arrese, mostraron, no solo mayor inconcreción, sino una irreprimible nostalgia. Su proyecto de leyes fundamentales, que pretendía resaltar las atribuciones del Movimiento y el poder del Consejo Nacional en la estructura del Estado, y que chocó con la oposición cerrada de las restantes familias del régimen e incluso de la Iglesia, resultó ser, en el fondo, el canto del cisne del fascismo español ${ }^{117}$. Y es que el proyecto autárquico, proteccionista y totalitario que seguían defendiendo los falangistas chocó con las necesidades de la economía española y con las líneas generales de la economía diseñadas por los organismos internacionales en que España se había ido integrando. A la altura de los años setenta, declararse falangista — diría el economista Juan Velarde - «ya no es una definición (...) Si algún falangista sostiene alguna idea debe decir que lo hace a título particular, porque como miembro de una organización nada puede decir (...) La falange se encuentra en un estado de pulverización, pues ni siquiera algunos grupos activistas y minoritarios que uno se encuentra en la Universidad, se entienden entre sí» ${ }^{118}$.

Finalizada la guerra mundial, Franco recurrió a los sectores de la Asociación Católica Nacional de Propagandistas. A diferencia de los falangistas y de los herederos de Acción Española, los hombres de Herrera nunca se distinguieron por la densidad conceptual de su pensamiento político; fueron más que nada hombres de acción. Su proyecto político tuvo por norte las encíclicas papales. Sus principales representantes fueron, aparte de Herrera, Fernando Martín SánchezJuliá, José Larraz, Alberto Martín Artajo y José María García Escudero ${ }^{119}$.

Mayor importancia tuvo, a nivel ideológico, la aparición en 1948 de lo que vino en llamarse, un tanto impropiamente, la «Tercera Fuerza», representada por los herederos ideológicos de Acción Española, entre los que destacaban algunos miembros de la sociedad religiosa Opus Dei, fundada en 1928 por el sacerdote José María Escrivá de Balaguer ${ }^{120}$, como Rafael Calvo Serer, Florentino Pérez-Embid, Ángel López-Amo, Vicente Marrero, Antonio Fontán, Antonio Millán Puelles, etc.; y al margen de ésta, Gonzalo Fernández de la Mora. Calvo

${ }^{116}$ MuÑoz Alonso, Adolfo: Persona bumana y sociedad, Madrid, 1955. Un pensador para un pueblo, Madrid, 1969.

${ }^{117}$ ARrESE, José Luis de: Obras seleccionadas, Madrid, 1966. Una etapa constituyente, Barcelona, 1982.

118 Serrats OlLÉ, Jaime: «El doctrinario Juan Velarde Fuertes», en Mundo, octubre 1972.

119 Vid. MARTín SÁNCHEZ-Juliá, Fernando: Ideas claras. Reflexiones de un español actual, Madrid, 1959. García EsCUdero, José María: Conversaciones sobre Ángel Herrera, Madrid, 1986.

120 Vid. Artigues, Daniel: El Opus Dei en España, París, 1970 Estruch, Joan: Santos y pillos. El Opus Dei y sus paradojas, Barcelona, 1994. 
Serer se sirvió para aglutinar a los intelectuales conservadores y tradicionalistas de la revista Arbor, órgano del Consejo Superior de Investigaciones Científicas. Su objetivo más inmediato era ofrecer una alternativa a los equipos políticos que hasta entonces habían monopolizado la dirección del Estado: una alternativa consistente en la institucionalización monárquica del régimen nacido de la guerra civil, favoreciendo un entendimiento entre Franco y Don Juan de Borbón; la restauración de la «conciencia nacional unitaria», basada en el catolicismo, frente a los intentos de apertura intelectual favorecidos por el ministro de Educación Nacional Joaquín Ruíz Jiménez y los falangistas; y en la asunción de las premisas del neocapitalismo y del desarrollo económico. Como diría Florentino Pérez-Embid: «españolización de los fines y europeización de los medios» ${ }^{121}$.

Dentro de la homogeneidad católica y monárquica de este sector intelectual, existía, sin embargo, una cierta heterogeneidad de perspectivas, cuyo polo máximo lo encarnaban Vicente Marrero - luego director de la revista neointegrista Punta Europa - y Fernández de la Mora. El pensamiento de Marrero pretendió asentarse sobre una perspectiva radicalmente católica, considerando irrenunciable el carácter de «Cruzada» dado a la guerra civil y la denuncia de la heterodoxia religiosa representada por Unamuno y, sobre todo, por Ortega ${ }^{122}$. Características muy distintas ofrecía el pensamiento de Fernández de la Mora, admirador de Ortega y partidario de eliminar el «patetismo» y de llegar a la «asepsia» técnica mediante la "desideologización», despojando de ingrediente religioso a la política y rehuyendo, de manera expresa, la denominación de «Cruzada» para la guerra civil ${ }^{123}$. Junto a Fernández de la Mora, los miembros más interesantes del grupo eran Leopoldo-Eulogio Palacios, antiguo colaborador de Acción Española y critico de Maritain, y Angel López-Amo, profesor del entonces Príncipe de España, e introductor de las teorías monárquicas de Lorenz von Stein ${ }^{124}$.

Calvo Serer dio igualmente audiencia a los últimos representantes del tradicionalismo carlista, como Francisco Elías de Tejada y Rafael Gambra. Iusfilósofo, historiador y doctrinario político, Elías de Tejada teorizó sobre la Monarquía tradicional, limitada mediante leyes fundamentales y los particularismos de los diferentes reinos de «las Españas» ${ }^{125}$. Mientras que Gambra intentó ac-

121 Calvo Serer, Rafael: España, sin problema, Madrid, 1949. Teoría de la Restauración, Madrid, 1952. PÉREZ EMBID, Florentino, Ambiciones españolas, Madrid, 1953, páginas 46 y ss.

122 MARrero, Vicente: La guerra civil española y el trust de cerebros, Madrid, 1965. Ortega, filósofo mondain, Madrid, 1960.

123 FERNÁNDEZ De la MORA, Gonzalo: Ortega y el 98, Madrid, 1961. El crepúsculo de las ideologías, Madrid, 1965.

${ }^{124}$ LÓPEZ-AMO, Ángel: Poder político y libertad. La Monarquía de la reforma social, Madrid, 1952. PALACIOS, Leopoldo-Eulogio, El mito de la Nueva Cristiandad, Madrid, 1952.

125 ReAl ACADEMIA DE CienCias MORAles y Políticas: Francisco Elías de Tejada y Spínola. El hombre y la obra, Madrid, 1989. AYUSO, Miguel: La filosofía jurídica y política de Francisco Elías de Tejada, Madrid, 1994.

Hispania, LXI/1, núm. 207 (2001) 99-142 
tualizar las teorías de Vázquez de Mella, para más tarde criticar el «derrotismo católico» incapaz de mantener la unidad religiosa nacional frente a las tendencias secularizadoras ${ }^{126}$.

Con el tiempo, la llamada «Tercera Fuerza» acabó disolviéndose; y algunos de sus miembros, como Calvo Serer, evolucionaron hacia posturas liberalconservadoras; mientras que otros, como Pérez-Embid y Fernández de la Mora, se integraron en el régimen. Fernández de la Mora fue el autor, junto a Laureano López Rodó, de las Leyes Fundamentales, convirtiéndose en el pensador por excelencia del último período del régimen de $\mathrm{Franco}^{127}$.

$\mathrm{Y}$ es que, para entonces, el conjunto de la derecha española iba a tener que enfrentarse a una serie de retos de singular transcendencia. Por de pronto, durante la década de los años sesenta la sociedad española iba a experimentar unas transformaciones sociales decisivas. Como consecuencia de un desarrollo económico sin precedentes, se agudizó la desintegración de la sociedad agraria tradicional, que provocó la concentración urbana de la mano de obra liberada de la agricultura; lo cual incidió en la secularización y «americanización» de las costumbres, que hizo entrar en profunda crisis los fundamentos de la cultura política tradicional de las derechas españolas. Unido a ello, se produjo un cambio verdaderamente cualitativo en la doctrina de la Iglesia católica, con el Concilio Vaticano II. Para la sociedad española, y en concreto para el régimen político, la situación inaugurada por las transformaciones sociales y, sobre todo, por el Concilio fue enormemente problemática. Porque el catolicismo no era sólo en España una religión; era todo un sistema de creencias y mores que había marcado a todo el país, sus ideas, su política; que había sido objeto de guerras internas y externas. Por eso, la crisis del catolicismo tradicional fue una crisis auténticamente nacional; y, sobre todo, política. Significó el final de toda una época de la historia de España. No es extraño que un viejo colaborador de Acción Española como Aniceto de Castro Albarrán, exclamara, al conocer el contenido del Concilio, «iPobre Iglesia! iPobre España!» ${ }^{128}$.

Frente a aquella situación, a la derecha tradicional le quedaron tan sólo dos opciones: permanecer aferrada a una institución, como la Iglesia católica, que ya no quería saber nada de ella, o buscar nuevas vías. Fernández de la Mora optó por el segundo de los caminos. A ese respecto, su obra se inscribe en el intento de dotar a la derecha tradicional española de nuevos horizontes intelectuales e ideológicos, adecuándola a las nuevas condiciones de desarrollo económico y secularización. Por ello, su producción no se limita a repetir los viejos tópicos; no es una mera refundición de tradiciones anteriores; integra unos elementos —el

126 GAMBRA, Rafael: La Monarquía social y representativa en el pensamiento tradicional, Madrid, 1954. La unidad religiosa y el derrotismo católico, Sevilla, 1965.

127 GonzÁlez Cuevas, Pedro Carlos: «Gonzalo Fernández de la Mora y la legitimación del franquismo", en Sistema, no 91, septiembre 1989. Razonalismo. Homenaje a Fernández de la Mora, Madrid, 1995.

128 CASTRO ALBARRÁN, Aniceto de: Lo nuevo conciliar y lo eclesial perenne, Madrid, 1967, página 101.

Hispania, LXI/1, núm. 207 (2001) 99-142 
elitismo, la critica a la democracia liberal, etc.- y otros no -el pasadismo, el antimodernismo, el fideísmo, el integrismo religioso-, los eleva de nivel y los proyecta en una realidad social distinta, donde cumplen una función diferente. Frente al integrismo tradicional, Fernández de la Mora asume un concepto racionalista —o «razonalista», como él lo denomina - de la historia, que es presentada como marcha progresiva del espíritu humano del «mithos al logos». Progreso es sinónimo de «racionalización» de los distintos aspectos de la vida humana; lo que tiene como consecuencia la asunción de la necesidad de modernización social, económica y política. De ahí que el ideal contemporáneo por antonomasia sea el desarrollo, cuyas consecuencias sociales y políticas - homogeneización de las clases sociales y de las naciones - llevan consigo la exigencia de nuevas fórmulas de legitimación y de representación política. Suponía el paso de la política «ideológica» a la política «científica»; lo que ponía en crisis a las ideologías tradicionales: nacionalismo, liberalismo, socialismo y democracia cristiana. Las ideologías eran «derivaciones», en el sentido de Pareto, es decir, filosofías políticas popularizadas, patetizadas, simplificadas. A partir de ahí, Fernández de la Mora critica al marxismo como anticientífico; al nacionalismo, como irracional; al confesionalismo religioso, como anacrónico en un periodo de «interiorización de creencias»; y al liberalismo, cuyo sistema económico era ya inviable y cuya sistema político degeneraba progresivamente en «partitocracia». En definitiva, la legitimidad del Estado no podía ya descansar en esas ideologías, sino en la «eficacia», es decir, en su capacidad para garantizar el orden, la justicia y el desarrollo económico. El Estado «ideológico» era sustituido por el «Estado de razón». Y, en ese sentido, el Estado nacido de la guerra civil adquiría legitimidad por el formidable cambio de infraestructuras ocurrido bajo su égida, por su política de orden y de justicia social; era un auténtico «Estado de obras». De la misma forma, el sistema de «democracia orgánica» era más eficaz que el liberal a la hora de representar los distintos intereses sociales y de frenar los avances de la partitocracia ${ }^{129}$.

Las tesis de Fernández de la Mora fueron muy discutidas; y no sólo por la izquierda, lo que era natural, sino igualmente, e incluso con más virulencia por algunos sectores de la derecha y la extrema derecha, que no podían aceptar ni su valoración positiva de la secularización, ni su renuncia a la confesionalidad del Estado, ni su apuesta por el cosmopolitismo frente al nacionalismo ${ }^{130}$. Para algunos intelectuales afines al régimen, su asunción de las tesis de Fernández de la Mora presagiaban su próximo fin ${ }^{131}$. Y, de hecho, no dejaba de ser cierto que la «eficacia» como criterio de legitimidad colocaba el régimen de Franco sobre un basamento, muy inestable y peligroso, pues ya no tenía justificación

${ }_{129}$ FernÁNDez De la MoRA, Gonzalo: El crepúsculo de las ideologías, Madrid, 1965. Del Estado ideal al Estado de razón, Madrid, 1972. El Estado de obras, Madrid, 1976. La partitocracia, Madrid, 1977.

130 Vid. Gambra, Rafael: Tradición o mimetismo, Madrid, 1976, páginas 80 y ss. MuÑoz Alonso, Adolfo: Un pensador para un pueblo, Madrid, 1969, páginas 145 y ss.

131 GonZÁlez CuEVAS, «Gonzalo Fernández de la Mora y...», en op. cit., páginas 95 y ss.

Hispania, LXI/1, núm. 207 (2001) 99-142 
en sí mismo, sino que se le entregaba a consideraciones relativas de utilidad que podían ser llevadas a cabo igualmente por otro tipo de sistema político.

\section{OCASO Y RENOVACIÓN}

De esta forma, el cambio político ocurrido tras la muerte de Franco sorprendió al conjunto de la extrema derecha española en una profunda crisis de identidad. Crisis que se ha prolongado hasta estos mismos momentos. Sin traducciones extranjeras respetables, sin el apoyo de las nuevas fuerzas económicas y financieras y, sobre todo, de la Iglesia católica, en una sociedad en permanente transformación, la extrema derecha tradicional, tanto en su versión falangista como en la tradicionalista-integrista, era ya, y desde hacía tiempo, una alternativa política inviable. Prueba de ello fue el fracaso experimentado por Fuerza Nueva, único grupo de extrema derecha que ofreció la imagen de funcionar como partido político a lo largo de la «transición» ${ }^{132}$. Frecuentemente se ha hablado de Fuerza Nueva como un conato de fascismo a la española; pero, en rigor, seria más próximo a la realidad considerarle como el último estertor de la tradición teológico-política española. Su líder, Blas Piñar López era -y es- un integrista, cuya ideología bebe sus fuentes en Acción Española, el tradicionalismo y ciertos aspectos del falangismo. «Soy joseantoniano y tradicionalista de una sola pieza (...) El tradicionalismo era algo así como la reserva no contaminada de nuestro pueblo, y la Falange el indignado movimiento surgido de la contaminación (...) desde el punto de vista religioso (...) somos integristas en lo dogmático y progresistas en lo pastoral» ${ }^{133}$. Un proyecto, como se vio, sin capacidad alguna de futuro, que acabó disolviéndose, sin llegar a arrancar como expresión de una extrema derecha moderna, semejante a la representada en Francia por Jean Marie Le Pen.

Y lo mismo ocurrió con el falangismo, dividido en múltiples facciones (FEJONS, Falange Española (Auténtica), Falange Española Independiente, etc.), e incapaz de articularse como partido político; y que, en realidad, desapareció como fuerza autónoma, hegemonizado por el grupo de Blas Piñar. A mediados de los años setenta, surgió en Barcelona el llamado Círculo Español de Amigos de Europa (CEDADE), como expresión tardía y marginal de un nacional-socialismo a la española, que acabó disolviéndose, tras un periodo de relativo auge, por sus propias contradicciones internas y por su escasa incidencia social ${ }^{134}$.

\footnotetext{
132 RODRÍGUEZ JIMÉNEZ, José Luis: Reaccionarios y golpistas. La extrema derecha en España: del tardofranquismo a la consolidación de la democracia (1967-1982), Madrid, 1995. CASALS, Xavier: La Tentación neofascista en España, Barcelona, 1998.

133 «Blas Piñar López», Dossier Mundo, mayo-junio 1971. PIÑar, Blas: Combate por España, Madrid, Hacia un Estado nacional, Madrid, 1979. ¿Hacia la Tercera República?, Madrid, 1978

134 Vid. CASALS, Xavier: Neonazis en España. De las audiciones wagnerianas a los skinheads (19661995), Barcelona, 1995.
} 
Mayor interés tuvieron los intentos de recepción española de la llamada «Nueva Derecha», movimiento ideológico surgido en Francia, que intenta renovar los viejos temas de la derecha radical europea. Su líder intelectual, Alain de Benoist, director de la Nouvelle École, afirma que las ideas centrales de la derecha radical, entre ellas las genética, la raza y la desigualdad, han sido desacreditadas por su vinculación al nacional-socialismo; y trata de insuflarlas nueva vida mediante el injerto en ellas de elementos de la sociobiología, la etnología y la etología. Como Maurras, Benoist adora el politeísmo pagano, porque consagra las diversidades naturales; y deplora el cristianismo, al que califica de «bolchevismo de la Antigüedad», porque ha preparado la homogeneización del mundo, luego recogida por el comunismo y el liberalismo norteamericano ${ }^{135}$.

Este nuevo paradigma no fue asumido por Fuerza Nueva, ni podía serlo; pero sí por algunos sectores de Alianza Popular, capitaneados por Jorge Verstrynge y, al menos en parte, por el propio Manuel Fraga, quienes invitaron a Benoist a dar una serie de conferencias en el Club del Sable ${ }^{136}$. No obstante, su contenido anticristiano fue muy criticado por diarios españoles, como $A B C$ y $E l$ Alcázar, si bien éste último publicó algunos artículos de Benoist. El paradigma neoderechista intentó popularizarse a través de una serie de revistas, como $F u$ turo-Presente, dirigida por el escritor rumano Vintila Horia, y que publicó artículos de Benoist, Evola y otros representantes de la «Nueva Derecha»; y luego por El Martillo, Disidencias, Punto y Coma, etc., sin lograr, en aquellos momentos, excesiva audiencia ${ }^{137}$.

Hoy, las cosas están comenzando a cambiar. De un lado, subsiste el viejo integrismo católico representado en la revista Verbo, de los «Amigos de la Ciudad Católica», donde han colaborado, entre otros, Blas Piñar, Eugenio Vegas, Gambra, Elías de Tejada, Álvaro D'Ors, Vallet de Goytisolo, etc. Su punto de referencia continua siendo el integrismo francés, representado, en su día, por Monseñor Marcel Lefebvre. Por su parte, el falangismo ha intentado actualizar su proyecto político. Y algunos de sus miembros intentan revalorizar la perspectiva laica y fáustica de Ledesma Ramos, mientras que otros dan una interpretación tradicionalista y católica del pensamiento de José Antonio Primo de Rivera ${ }^{138}$.

Distinta y mucho más interesante es la perspectiva dominante en Razón Española, revista fundada en 1983, y que dirige Gonzalo Fernández de la Mora,

135 BENOIST, Alain de: La Nueva Derecha, Barcelona, 1982. BeNOIST, Alain de y FAYE, Guillaume, Las ideas de la Nueva Derecha, Barcelona, 1986.

136 CASALS, op. cit., páginas 145 y ss.

137 Ibidem, páginas, 165 y ss. Del mismo autor, «La ultraderecha española, ¿una modernización imposible?», en PÉREZ LeDESMA, Manuel (comp.): Los riesgos de la democracia. Fascismo y Neofascismo, Madrid, 1997, páginas 171 y ss.

138 Vid. MORALES, Gustavo: De la protesta a la propuesta, Madrid, 1996. CuAdrado CosTA, José: Ramiro Ledesma Ramos, un romanticismo de acero, Madrid, 1990. QUINTANILLA, R.S. y LLOPART, Juan Antonio: Ramiro Ledesma Ramos, ¿un nacional-bolchevique?, Barcelona, 1996. ARGAYA ROCA, Miguel: Entre lo espontáneo y lo difícil, Oviedo, 1996.

Hispania, LXI/1, núm. 207 (2001) 99-142 
logrando aglutinar en sus páginas tanto a los intelectuales fieles al régimen de Franco como a jóvenes representantes de las nuevas tendencias derechistas. Fiel a su paradigma «razonalista», Fernández de la Mora considera que «el racionalismo es un método conservador». Y la revista que dirige ha asumido, al lado de los temas tradicionales de la derecha española, la perspectiva racionalista crítica de Karl Popper, el conservadurismo de Michael Novak, las aportaciones de Hayek en el campo de la economía y de la política, al igual que las de la "public choice» de Buchanan, etc. Fernández de la Mora se ha mostrado, no obstante, muy crítico con algunos aspectos de la ideología de la «Nueva Derecha», sobre todo en lo relacionado con la reivindicación del paganismo y del politeísmo, que considera de dudosa racionalidad ${ }^{139}$.

Más vinculada al paradigma neoderechista, aunque sin tocar sus temas anticristianos y racistas, se encuentra la revista Hespérides, órgano intelectual del Proyecto Aurora, cuyo director es el joven pensador y periodista José Javier Esparza. Su proyecto bebe en fuentes diversas: Jünger, Schmitt, Benoist, Gehlen, Spengler, Gramsci, la Escuela de Frankfurt, Heidegger, los comunitaristas norteamericanos (Taylor, Etzioni, etc.), Konrad Lorenz, la teoría de sistemas de Von Bertalanffy, Ortega y Gasset, etc. La ofensiva de Hespérides se vuelve contra los valores de la modernidad, aunque desde una perspectiva laica. El individualismo, el igualitarismo, progresismo y cosmopolitismo son sólo «una simple máscara para justificar la expansión universal de la técnica y del mercado». Se trata de una defensa de las identidades nacionales frente a la progresiva homogeneización mundialista, que el proyecto de la modernidad lleva en sí. Frente al cual, se propugna una sociedad construida sobre «solidaridades orgánicas», la «resurrección del sentido de lo sagrado», políticas ecológicas, un nuevo sistema económico y una nueva concepción de la nacionalidad española ${ }^{140}$. Son estos, sin duda, unos discursos que rompen definitivamente con algunas de las tradiciones más arraigadas de la derecha y de extrema derecha españolas; que miran más al futuro que al pasado; y que tienen, a nuestro juicio, la suficiente capacidad persuasiva para fascinar, en un momento de crisis como el que vivimos, a un creciente número de personas. Por otra parte, algunos de los peligros que denuncian son reales, aunque no nos gusten sus soluciones. Y, en ese sentido, sus palabras, sus escritos pueden inquietar. Pero estos planteamientos no pueden ser criticados en la cejijunta, cómoda y embobada beatería tan al uso de un supuesto "mal absoluto», sino con la ayuda de ese soberano principio vital de la inteligencia: el espíritu crítico.

139 Razón Española, n 61, septiembre-octubre 1993, páginas 246-248. FERNÁNDEZ DE LA MORA, Gonzalo: La envidia igualitaria, Barcelona, 1986. Los errores del cambio, Barcelona, 1992. El hombre en desazón. Oviedo, 1998.

140 «Defensa contra la vieja y la nueva Inquisición», Hespérides, n 14, verano 1997, páginas 334 y ss. ESPARZA, José Javier: Ejercicios de vértigo, Madrid, 1994. Curso General de Disidencia, Madrid, 1997.

Hispania, LXI/1, núm. 207 (2001) 99-142 